\title{
SHOCK WAVE EQUATION OF STATE OF SERPENTINE TO 150 GPA: IMPLICATIONS FOR THE OCCURRENCE OF WATER IN THE EARTH'S LOWER MANTLE
}

\author{
James A. Tyburczy
}

Department of Geology, Arizona State University, Tempe

Thomas S. Duffy, Thomas J. Ahrens, and Manfred A. Langel

Seismological Laboratory, California Institute of Technology, Pasadena

\begin{abstract}
The shock equation of state of serpentine has been determined to $150 \mathrm{GPa}$. Four distinct regions occur along the Hugoniot: a low-pressure phase, a mixed phase region, a high-pressure phase, and a very high pressure phase. The low-pressure phase (LPP) exists under shock pressures to about $40 \mathrm{GPa}$. This material exhibits shock properties that are partially consistent with those of low pressure serpentine, but steep release paths and a low value of $\mathrm{K}^{\prime}=2.77$ suggest transformation to another, possibly amorphous, assemblage. Thermodynamic calculations indicate that under equilibrium conditions, serpentine would decompose to oxides plus water at conditions below $10 \mathrm{GPa}$ along the Hugoniot. A mixed phase region begins at $40 \mathrm{GPa}$ with complete transition to a high-pressure phase occurring by about $55 \mathrm{GPa}$. The high-pressure phase (HPP) occurs at shock pressures between $55 \mathrm{GPa}$ and $125 \mathrm{GPa}$. Model Hugoniots based on perovskite plus periclase plus water and brucite plus periclase plus stishovite reproduce the serpentine HPP Hugoniot within experimental error, so definitive identification of the HPP as a distinct hydrous mineral phase or as a free water containing mixture is not possible. Above $125 \mathrm{GPa}$ a transition to a very compressible phase, possibly a hydrous partial melt, occurs. The serpentine HPP Hugoniot is about $15-20 \%$ less dense than the Earth's lower mantle. Models of the lower mantle based on shock equations of state for olivine, pyroxene, and serpentine indicate that for an atomic $\mathrm{Mg} /(\mathrm{Mg}+\mathrm{Fe})$ ratio of 0.80 , the presence of $2 \mathrm{wt} \%$ $\mathrm{H}_{2} \mathrm{O}$ is consistent with seismically determined lower mantle density estimates. Greater amounts of $\mathrm{H}_{2} \mathrm{O}$ can be accommodated if accompanied by an increase in $\mathrm{Fe}$ content. Calculated Hugoniot sound speeds of the serpentine HPP, although poorly constrained, are broadly consistent with lower mantle sound speeds. Thus the high-pressure density and sound speed of an $\mathrm{H}_{2} \mathrm{O}$-rich magnesium silicate determined from shock equation of state experiments indicate that the observed seismic properties of the lower mantle allow the existence of several weight percent of water in the lower mantle.
\end{abstract}

\footnotetext{
${ }^{1}$ Now at Alfred Wegener Institute for Polar and Marine Research, Bremerhaven, Federal Republic of Germany.

Copyright 1991 by the American Geophysical Union.
}

Paper number 91JB01573.

0148-0227/91/91JB-01573\$05.00
Introduction

The discovery and characterization of hydrous magnesium silicates that are stable to at least the pressures and temperatures of the Earth's upper mantle raise the question of their stability and existence as $\mathrm{H}_{2} \mathrm{O}$ reservoirs within the Earth's lower mantle [Ringwood and Major, 1967; Yamamoto and Akimoto, 1977; Akaogi and Akimoto, 1980; Liu, 1986, 1987; Finger et al., 1989]. Occurrence of significant amounts of $\mathrm{H}_{2} \mathrm{O}$ in the Earth's interior would strongly influence the petrological and thermal evolution of the planet [e.g., Liu, 1987; Finger et al., 1989; McGovern and Schubert, 1989]. However, detailed phase relations and the ultimate pressuretemperature stability range of these phases have yet to be determined. Also currently lacking are equation of state data that would allow comparison with Earth density and seismic velocity models. Shock wave studies can constrain the equation of state of high-pressure minerals. The shock and release properties of hydrous minerals are also of interest in the study of meteorite and planetesimal impacts, impactinduced devolatilization, and atmospheric evolution [Zahnle et al., 1988; Ahrens et al., 1989]. We have performed shock Hugoniot and release experiments at shock pressures up to $150 \mathrm{GPa}$ on polycrystalline, magnesium end-member serpentine to determine its high pressure equation of state. The results are compared to global density and seismic velocity profiles to constrain the possible $\mathrm{H}_{2} \mathrm{O}$ content of the Earth's lower mantle.

The Hugoniot to $88 \mathrm{GPa}$ of a serpentinized rock from VerMyen, Italy, has been determined by McQueen (compiled by Marsh [1980]). This material has an initial density of 2.80 $\mathrm{g} / \mathrm{cm}^{3}$ and has a total $\mathrm{Mg} /[\mathrm{Mg}+\mathrm{Fe}]$ ratio of 0.9 , whereas pure $\mathrm{Mg}$ end-member serpentine has a density of $2.50-2.55 \mathrm{~g} / \mathrm{cm}^{3}$. Optical microscopic examination of the Ver-Myen serpentine reveals that it is an incompletely metamorphosed ultramafic rock; a number of the individual mineral grains comprising the rock consist of olivine and orthopyroxene cores surrounded by serpentine. Thus the $\mathrm{H}_{2} \mathrm{O}$ content is not known and is not uniformly distributed. This material undergoes a transition to a mixed phase at about $40 \mathrm{GPa}$ on the Hugoniot that is complete by about $70 \mathrm{GPa}$. To determine the shock equation of state of pure, magnesium end-member serpentine, we examined the shock properties of three polycrystalline serpentines: (1) a lizardite serpentine found near Globe, Arizona, (2) an antigorite serpentine from Thurman, New York, and (3) a chrysotile serpentine from Quebec, Canada. 


\section{Experimental Procedures}

Bulk chemical analyses of the three serpentines studied are given in Table 1. Atomic $\mathrm{Mg} / \mathrm{Si}$ ratios lie between 1.48 and 1.53. The $\mathrm{H}_{2} \mathrm{O}$ content is between $12.7 \mathrm{wt} \%$ and $15.2 \mathrm{wt} \%$. The ideal serpentine (chrysotile) chemical formula is $\mathrm{Mg}_{3} \mathrm{Si}_{2} \mathrm{O}_{5}(\mathrm{OH})_{4}$ and contains 13.0 wt $\% \mathrm{H}_{2} \mathrm{O}$. Optical examination and powder $\mathrm{X}$ ray diffraction analyses indicate the presence of no other minerals in the samples. Initial densities of $2.50-2.52 \mathrm{~g} / \mathrm{cm}^{3}$ are within $2 \%$ of the ideal theoretical density of $2.55 \mathrm{~g} / \mathrm{cm}^{3}$ [Robie et al., 1978]. Archimedean densities (determined by weighing the samples in air and in toluene) and bulk densities (calculated using sample

TABLE 1. Chemical Composition of Materials Studied

\begin{tabular}{cccc}
\hline & Lizardite & Antigorite & Chrysotile \\
Location & $\begin{array}{c}\text { Globe, } \\
\text { Arizona }\end{array}$ & $\begin{array}{c}\text { Thurman, } \\
\text { New York }\end{array}$ & $\begin{array}{c}\text { Quebec, } \\
\text { Canada }\end{array}$ \\
& & & \\
$\mathrm{SiO}_{2}$ & 42.28 & 40.30 & 39.91 \\
$\mathrm{TiO}_{2}$ & 0.04 & 0.04 & 0.01 \\
$\mathrm{Al}_{2} \mathrm{O}_{3}$ & 0.42 & 0.22 & 0.78 \\
$\mathrm{CaO}$ & 0.03 & 2.32 & 0.01 \\
$\mathrm{MgO}$ & 41.94 & 41.51 & 39.59 \\
$\mathrm{FeO}$ & $0.36 *$ & - & $1.19 *$ \\
$\mathrm{Fe}_{2} \mathrm{O}_{3}$ & - & $0.60 * *$ & - \\
$\mathrm{MnO}$ & 0.08 & 0.02 & 0.06 \\
$\mathrm{~K}_{2} \mathrm{O}$ & 0.02 & 0.01 & 0.02 \\
$\mathrm{Na}_{2} \mathrm{O}$ & 0.01 & 0.08 & 0.01 \\
$\mathrm{H}_{2} \mathrm{O}$ & 12.70 & 15.20 & 14.00 \\
& 97.88 & 100.30 & 95.58 \\
& & & \\
Density, g/cm & 2.50 & 2.52 & 2.52 \\
\hline
\end{tabular}

Oxides in weight percent.

$\mathrm{H}_{2} \mathrm{O}$ analysis by thermogravimetric analysis.

*Analysis by electron microprobe; all $\mathrm{Fe}$ reported as $\mathrm{FeO}$.

**Analysis by X-ray fluoresence; all $\mathrm{Fe}$ reported as $\mathrm{Fe}_{2} \mathrm{O}_{3}$. dimensions and mass) differed by less than $2 \%$ in all cases.

The shock wave experiments were carried out using either a two-stage light gas gun (LGG) or a $40 \mathrm{~mm}$ bore propellant gun (40 mm gun). The experimental methods have been presented elsewhere and are discussed here only briefly [Ahrens et al., 1977; Jeanloz and Ahrens, 1980; Ahrens, 1987]. In each experiment, the impact velocity of the projectile and the shock velocity through the sample and through buffer materials mounted on the rear surface of the sample are measured. The projectile velocity is determined using flash $\mathrm{X}$ ray radiography; shock wave velocities are determined using rear surface arrival mirrors and streak camera photography. The shock Hugoniot state is calculated using impedance matching conditions and a partial or fully released state is determined using the Riemann integral method [Rice et al., 1958; Lyzenga and Ahrens, 1978]. The shock equations of state of the projectile ( $\mathrm{Al}, \mathrm{W}, \mathrm{Ta}$, and $\mathrm{Pt}$ ) and buffer materials (polystyrene foam, graphite foam, and lexan) are listed along with their sources in Table 2. For some of the shots, streak camera cutoffs could be observed for both the centrally mounted buffer material (usually polystyrene foam) and for the lexan sample arrival mirrors mounted on the rear sample surface on either side of the central buffer material. Thus a single shock experiment occasionally yielded two partially released state data points. The Hugoniot and release state data are listed in Table 3. Errors in the derived parameters are estimated by propagating the errors of the measured parameters through the impedance match relations [Bevington, 1969; Jackson and Ahrens, 1979].

\section{Results}

The experimental results are listed in Table 3 and shown in Figures 1 and 2. For the shots numbered 544 ( $40 \mathrm{~mm}$ gun) and 187 (LGG), the results lie significantly outside the error limits of the rest of the data. The results for these shots are listed in Table 3 but are not considered in the data analysis and discussion that follow. The results for the antigorite, lizardite, and chrysotile polymorphs of serpentine are indistinguishable and are treated together in the following discussion. Figures 1

TABLE 2. Shock Equation of State Parameters of Flyer and Buffer Materials

\begin{tabular}{|c|c|c|c|c|c|}
\hline Material & $\begin{array}{c}\text { Range of } u_{p}, \\
\mathrm{~km} / \mathrm{s}\end{array}$ & $\begin{array}{l}\text { Density, } \\
\mathrm{g} / \mathrm{cm}^{3}\end{array}$ & $\begin{array}{r}\mathrm{C}_{\mathrm{o}} \\
\mathrm{km} / \mathrm{s}\end{array}$ & $\mathrm{s}$ & $\gamma_{0}$ \\
\hline Polystyrene (PS)a & $0-4.8$ & 0.0497 & 0.243 & 1.118 & \\
\hline Lexan $^{\mathbf{a}}$ & $\begin{array}{l}>5.56 \\
0-3.0\end{array}$ & 1.193 & $\begin{array}{r}-0.493 \\
2.449\end{array}$ & $\begin{array}{l}1.354 \\
1.498\end{array}$ & \\
\hline Graphite (Gr) & $>3.0$ & 1.081 & $\begin{array}{l}2.419 \\
0.79\end{array}$ & $\begin{array}{l}1.321 \\
1.30\end{array}$ & \\
\hline $\mathrm{Al}^{\mathrm{a}}$ & & 2.785 & 5.328 & 1.338 & \\
\hline $\begin{array}{l}\mathrm{Ta} b, c \\
\mathrm{~W}^{\mathrm{a}}\end{array}$ & & $\begin{array}{l}16.656 \\
19.224\end{array}$ & $\begin{array}{l}3.293 \\
4.029\end{array}$ & $\begin{array}{l}1.307 \\
1.237\end{array}$ & 1.8 \\
\hline$P t d, e$ & & 21.44 & 3.633 & 1.472 & 2.4 \\
\hline
\end{tabular}

\footnotetext{
aMarsh [1980]

bMitchell and Nellis [1981]

cBrown and Shaner [1984]

dMorgan [1974]

eHolmes et al. [1989]
} 
TABLE 3. Serpentine Hugoniot Data

\begin{tabular}{|c|c|c|c|c|c|c|c|c|c|c|c|c|}
\hline \multirow[b]{2}{*}{$\begin{array}{c}\text { Shot Number } \\
\text { Flyer }\end{array}$} & \multirow[b]{2}{*}{ Material } & \multirow[b]{2}{*}{$\begin{array}{l}V_{\text {proj, }} \\
\mathrm{km} / \mathrm{s}\end{array}$} & \multirow[b]{2}{*}{$\begin{array}{c}\rho_{0} \\
\mathrm{~g} / \mathrm{cm}^{3}\end{array}$} & \multicolumn{4}{|c|}{ Hugoniot } & \multirow[b]{2}{*}{ Buffer } & \multicolumn{4}{|c|}{ Release State } \\
\hline & & & & $\begin{array}{c}\mathrm{U}_{\mathrm{s}} \\
\mathrm{km} / \mathrm{s}\end{array}$ & $\begin{array}{c}u_{p}, \\
\mathrm{~km} / \mathrm{s}\end{array}$ & $\begin{array}{r}\text { PHug, } \\
\text { GPa }\end{array}$ & $\begin{array}{l}\text { PHug, } \\
\mathrm{g} / \mathrm{cm}^{3}\end{array}$ & & $\begin{array}{c}\mathrm{U}_{\mathrm{s}}, \text { buffer } \\
\mathrm{km} / \mathrm{s}\end{array}$ & $\begin{array}{l}\text { Urelease } \\
\mathrm{km} / \mathrm{s}\end{array}$ & $\begin{array}{c}\mathbf{P}_{\text {release }} \\
\mathrm{GPa}\end{array}$ & $\begin{array}{c}\rho_{\text {release }} \\
\mathrm{g} / \mathrm{cm}^{3}\end{array}$ \\
\hline 40-683-Al & lizardite & $\begin{array}{l}0.813 \\
0.011\end{array}$ & $\begin{array}{l}2.513 \\
0.010\end{array}$ & $\begin{array}{l}5.71 \\
0.04\end{array}$ & $\begin{array}{l}0.431 \\
0.011\end{array}$ & $\begin{array}{l}6.20 \\
0.14\end{array}$ & $\begin{array}{l}2.719 \\
0.007\end{array}$ & PS & $\begin{array}{l}0.778 \\
0.003\end{array}$ & $\begin{array}{l}0.479 \\
0.003\end{array}$ & $\begin{array}{l}0.02 \\
0.01\end{array}$ & $\begin{array}{l}2.716 \\
0.007\end{array}$ \\
\hline $40-682-\mathrm{Al}$ & lizardite & $\begin{array}{l}1.006 \\
0.065\end{array}$ & $\begin{array}{l}2.522 \\
0.010\end{array}$ & $\begin{array}{l}5.60 \\
0.02\end{array}$ & $\begin{array}{l}0.543 \\
0.038\end{array}$ & $\begin{array}{l}7.67 \\
0.53\end{array}$ & $\begin{array}{l}2.793 \\
0.021\end{array}$ & PS & $\begin{array}{l}0.855 \\
0.002\end{array}$ & $\begin{array}{l}0.548 \\
0.002\end{array}$ & $\begin{array}{l}0.02 \\
0.01\end{array}$ & $\begin{array}{l}2.791 \\
0.022\end{array}$ \\
\hline $40-668-W$ & lizardite & $\begin{array}{l}1.476 \\
0.040\end{array}$ & $\begin{array}{l}2.527 \\
0.002\end{array}$ & $\begin{array}{l}6.38 \\
0.14\end{array}$ & $\begin{array}{l}1.236 \\
0.034\end{array}$ & $\begin{array}{l}19.94 \\
0.65\end{array}$ & $\begin{array}{l}3.134 \\
0.028\end{array}$ & PS & $\begin{array}{l}2.527 \\
0.075\end{array}$ & $\begin{array}{l}2.043 \\
0.067\end{array}$ & $\begin{array}{l}0.25 \\
0.02\end{array}$ & $\begin{array}{l}2.840 \\
0.066\end{array}$ \\
\hline $40-676-W$ & antigorite & $\begin{array}{l}1.638 \\
0.041\end{array}$ & $\begin{array}{l}2.540 \\
0.002\end{array}$ & $\begin{array}{l}6.23 \\
0.06\end{array}$ & $\begin{array}{l}1.378 \\
0.035\end{array}$ & $\begin{array}{c}21.78 \\
0.58\end{array}$ & $\begin{array}{l}3.262 \\
0.026\end{array}$ & PS & $\begin{array}{l}3.016 \\
0.042\end{array}$ & $\begin{array}{l}2.480 \\
0.038\end{array}$ & $\begin{array}{l}0.35 \\
0.01\end{array}$ & $\begin{array}{l}2.752 \\
0.063\end{array}$ \\
\hline $40-662-W$ & lizardite & $\begin{array}{l}2.122 \\
0.030\end{array}$ & $\begin{array}{l}2.493 \\
0.010\end{array}$ & $\begin{array}{l}6.89 \\
0.07\end{array}$ & $\begin{array}{l}1.768 \\
0.026\end{array}$ & $\begin{array}{c}30.38 \\
0.51\end{array}$ & $\begin{array}{l}3.354 \\
0.024\end{array}$ & PS & $\begin{array}{l}4.559 \\
0.042\end{array}$ & $\begin{array}{l}3.860 \\
0.038\end{array}$ & $\begin{array}{l}0.97 \\
0.02\end{array}$ & $\begin{array}{l}2.237 \\
0.046\end{array}$ \\
\hline $40-552-W$ & chrysotile & $\begin{array}{l}2.300 \\
0.100\end{array}$ & $\begin{array}{l}2.519 \\
0.012\end{array}$ & $\begin{array}{l}6.52 \\
0.20\end{array}$ & $\begin{array}{l}1.932 \\
0.086\end{array}$ & $\begin{array}{c}31.71 \\
1.63\end{array}$ & $\begin{array}{l}3.581 \\
0.087\end{array}$ & PS & $\begin{array}{l}4.534 \\
0.217\end{array}$ & $\begin{array}{l}3.838 \\
0.194\end{array}$ & $\begin{array}{l}0.97 \\
0.10\end{array}$ & $\begin{array}{l}2.516 \\
0.205\end{array}$ \\
\hline $40-551-W$ & chrysotile & $\begin{array}{l}2.275 \\
0.100\end{array}$ & $\begin{array}{l}2.519 \\
0.012\end{array}$ & $\begin{array}{l}6.78 \\
0.22\end{array}$ & $\begin{array}{l}1.899 \\
0.085\end{array}$ & $\begin{array}{c}32.43 \\
1.70\end{array}$ & $\begin{array}{l}3.500 \\
0.081\end{array}$ & Gr & $\begin{array}{l}4.461 \\
0.195\end{array}$ & $\begin{array}{l}2.824 \\
0.150\end{array}$ & $\begin{array}{c}13.61 \\
1.32\end{array}$ & $\begin{array}{l}3.020 \\
0.226\end{array}$ \\
\hline $40-545-W$ & chrysotile & $\begin{array}{l}2.390 \\
0.010\end{array}$ & $\begin{array}{l}2.519 \\
0.012\end{array}$ & $\begin{array}{l}6.76 \\
0.24\end{array}$ & $\begin{array}{l}1.998 \\
0.086\end{array}$ & $\begin{array}{c}34.01 \\
1.77\end{array}$ & $\begin{array}{l}3.577 \\
0.089\end{array}$ & Gr & $\begin{array}{l}4.891 \\
0.875\end{array}$ & $\begin{array}{l}3.155 \\
0.673\end{array}$ & $\begin{array}{c}16.68 \\
6.54\end{array}$ & $\begin{array}{l}2.804 \\
0.952\end{array}$ \\
\hline $40-669-W$ & lizardite & $\begin{array}{l}2.452 \\
0.042\end{array}$ & $\begin{array}{l}2.485 \\
0.020\end{array}$ & $\begin{array}{l}6.76 \\
0.05\end{array}$ & $\begin{array}{l}2.055 \\
0.037\end{array}$ & $\begin{array}{c}34.53 \\
0.66\end{array}$ & $\begin{array}{l}3.569 \\
0.038\end{array}$ & $\begin{array}{c}\text { PS } \\
\text { Lexan }\end{array}$ & $\begin{array}{l}4.202 \\
0.044 \\
6.363 \\
0.270\end{array}$ & $\begin{array}{l}3.541 \\
0.039 \\
2.569 \\
0.172\end{array}$ & $\begin{array}{c}0.71 \\
0.02 \\
19.55 \\
2.14\end{array}$ & $\begin{array}{l}2.894 \\
0.063 \\
3.358 \\
0.173\end{array}$ \\
\hline $40-546-W$ & chrysotile & $\begin{array}{l}2.386 \\
0.100\end{array}$ & $\begin{array}{l}2.519 \\
0.012\end{array}$ & $\begin{array}{l}7.17 \\
0.25\end{array}$ & $\begin{array}{l}1.976 \\
0.085\end{array}$ & $\begin{array}{c}35.71 \\
1.85\end{array}$ & $\begin{array}{l}3.477 \\
0.078\end{array}$ & PS & $\begin{array}{l}5.509 \\
0.330\end{array}$ & $\begin{array}{l}4.710 \\
0.295\end{array}$ & $\begin{array}{l}1.45 \\
0.18\end{array}$ & $\begin{array}{l}1.977 \\
0.218\end{array}$ \\
\hline $40-648-W / A l$ & lizardite & $\begin{array}{l}2.473 \\
0.092\end{array}$ & $\begin{array}{l}2.504 \\
0.001\end{array}$ & $\begin{array}{l}7.04 \\
0.53\end{array}$ & $\begin{array}{l}2.175 \\
0.107\end{array}$ & $\begin{array}{c}38.35 \\
2.33\end{array}$ & $\begin{array}{l}3.624 \\
0.181\end{array}$ & & & & & \\
\hline LGG-176-Al & lizardite & $\begin{array}{l}4.141 \\
0.004\end{array}$ & $\begin{array}{l}2.450 \\
0.100\end{array}$ & $\begin{array}{l}6.79 \\
0.04\end{array}$ & $\begin{array}{l}2.338 \\
0.075\end{array}$ & $\begin{array}{c}38.87 \\
0.36\end{array}$ & $\begin{array}{l}3.738 \\
0.090\end{array}$ & PS & $\begin{array}{l}4.953 \\
0.056\end{array}$ & $\begin{array}{l}4.213 \\
0.050\end{array}$ & $\begin{array}{l}1.04 \\
0.02\end{array}$ & $\begin{array}{l}2.774 \\
0.040\end{array}$ \\
\hline $40-544-W$ & chrysotile & $\begin{array}{l}2.378 \\
0.100\end{array}$ & $\begin{array}{l}2.519 \\
0.012\end{array}$ & $\begin{array}{l}8.25 \\
0.31\end{array}$ & $\begin{array}{l}1.925 \\
0.084\end{array}$ & $\begin{array}{c}40.00 \\
2.12\end{array}$ & $\begin{array}{l}3.286 \\
0.063\end{array}$ & PS & $\begin{array}{l}5.198 \\
0.263\end{array}$ & $\begin{array}{l}4.432 \\
0.235\end{array}$ & $\begin{array}{l}1.29 \\
0.13\end{array}$ & $\begin{array}{l}2.142 \\
0.174\end{array}$ \\
\hline LGG-177-Al & lizardite & $\begin{array}{l}4.468 \\
0.005\end{array}$ & $\begin{array}{l}2.506 \\
0.010\end{array}$ & $\begin{array}{l}7.01 \\
0.07\end{array}$ & $\begin{array}{l}2.494 \\
0.012\end{array}$ & $\begin{array}{c}43.80 \\
0.26\end{array}$ & $\begin{array}{l}3.891 \\
0.029\end{array}$ & PS & $\begin{array}{l}5.989 \\
0.292\end{array}$ & $\begin{array}{l}5.140 \\
0.261\end{array}$ & $\begin{array}{l}1.53 \\
0.15\end{array}$ & $\begin{array}{l}2.367 \\
0.187\end{array}$ \\
\hline LGG-177-Al & lizardite & $\begin{array}{l}4.468 \\
0.005\end{array}$ & $\begin{array}{l}2.506 \\
0.010\end{array}$ & $\begin{array}{l}7.01 \\
0.07\end{array}$ & $\begin{array}{l}2.494 \\
0.012\end{array}$ & $\begin{array}{c}43.80 \\
0.26\end{array}$ & $\begin{array}{l}3.891 \\
0.029\end{array}$ & PS & $\begin{array}{l}5.989 \\
0.292\end{array}$ & $\begin{array}{l}5.140 \\
0.261\end{array}$ & $\begin{array}{l}1.53 \\
0.15\end{array}$ & $\begin{array}{l}2.367 \\
0.187\end{array}$ \\
\hline LGG-179-Al & lizardite & $\begin{array}{l}4.546 \\
0.006\end{array}$ & $\begin{array}{l}2.500 \\
0.010\end{array}$ & $\begin{array}{l}6.90 \\
0.06\end{array}$ & $\begin{array}{l}2.561 \\
0.011\end{array}$ & $\begin{array}{c}44.15 \\
0.24\end{array}$ & $\begin{array}{l}3.977 \\
0.027\end{array}$ & PS & $\begin{array}{l}5.412 \\
0.116\end{array}$ & $\begin{array}{l}4.624 \\
0.103\end{array}$ & $\begin{array}{l}1.24 \\
0.05\end{array}$ & $\begin{array}{l}2.852 \\
0.084\end{array}$ \\
\hline LGG-179-Al & lizardite & $\begin{array}{l}4.546 \\
0.006\end{array}$ & $\begin{array}{l}2.500 \\
0.010\end{array}$ & $\begin{array}{l}6.90 \\
0.06\end{array}$ & $\begin{array}{l}2.561 \\
0.011\end{array}$ & $\begin{array}{c}44.15 \\
0.24\end{array}$ & $\begin{array}{l}3.977 \\
0.027\end{array}$ & PS & $\begin{array}{l}5.412 \\
0.116\end{array}$ & $\begin{array}{l}4.624 \\
0.103\end{array}$ & $\begin{array}{l}1.24 \\
0.05\end{array}$ & $\begin{array}{l}2.852 \\
0.084\end{array}$ \\
\hline LGG-187-Al & lizardite & $\begin{array}{l}5.413 \\
0.006\end{array}$ & $\begin{array}{l}2.511 \\
0.010\end{array}$ & $\begin{array}{l}7.20 \\
0.13\end{array}$ & $\begin{array}{l}3.064 \\
0.021\end{array}$ & $\begin{array}{c}55.40 \\
0.65\end{array}$ & $\begin{array}{l}4.372 \\
0.080\end{array}$ & PS & $\begin{array}{l}6.207 \\
0.149\end{array}$ & $\begin{array}{l}5.335 \\
0.133\end{array}$ & $\begin{array}{l}1.65 \\
0.08\end{array}$ & $\begin{array}{l}3.081 \\
0.117\end{array}$ \\
\hline LGG-178-Al & lizardite & $\begin{array}{l}5.726 \\
0.007\end{array}$ & $\begin{array}{l}2.508 \\
0.010\end{array}$ & $\begin{array}{l}7.70 \\
0.06\end{array}$ & $\begin{array}{l}3.189 \\
0.013\end{array}$ & $\begin{array}{c}61.62 \\
0.34\end{array}$ & $\begin{array}{l}4.279 \\
0.035\end{array}$ & PS & $\begin{array}{l}7.669 \\
0.098\end{array}$ & $\begin{array}{l}6.028 \\
0.072\end{array}$ & $\begin{array}{l}2.30 \\
0.06\end{array}$ & $\begin{array}{l}2.706 \\
0.054\end{array}$ \\
\hline LGG-180-Al & lizardite & $\begin{array}{l}6.252 \\
0.007\end{array}$ & $\begin{array}{l}2.510 \\
0.010\end{array}$ & $\begin{array}{l}8.29 \\
0.06\end{array}$ & $\begin{array}{l}3.433 \\
0.013\end{array}$ & $\begin{array}{c}71.43 \\
0.36\end{array}$ & $\begin{array}{l}4.285 \\
0.031\end{array}$ & PS & $\begin{array}{l}8.119 \\
0.090\end{array}$ & $\begin{array}{l}6.360 \\
0.066\end{array}$ & $\begin{array}{l}2.57 \\
0.06\end{array}$ & $\begin{array}{l}2.795 \\
0.048\end{array}$ \\
\hline LGG-184-Ta & lizardite & $\begin{array}{l}5.057 \\
0.007\end{array}$ & $\begin{array}{l}2.514 \\
0.010\end{array}$ & $\begin{array}{l}9.19 \\
0.08\end{array}$ & $\begin{array}{l}3.920 \\
0.010\end{array}$ & $\begin{array}{c}90.55 \\
0.66\end{array}$ & $\begin{array}{l}4.385 \\
0.034\end{array}$ & PS & $\begin{array}{l}7.581 \\
0.132\end{array}$ & $\begin{array}{l}5.963 \\
0.097\end{array}$ & $\begin{array}{l}2.25 \\
0.08\end{array}$ & $\begin{array}{l}3.631 \\
0.064\end{array}$ \\
\hline
\end{tabular}


TABLE 3. (continued)

\begin{tabular}{|c|c|c|c|c|c|c|c|c|c|c|c|c|}
\hline \multirow[b]{2}{*}{$\begin{array}{c}\text { Shot Number } \\
\text { Flyer }\end{array}$} & \multirow[b]{2}{*}{ Material } & \multirow[b]{2}{*}{$\begin{array}{l}V_{\text {proj, }} \\
\mathrm{km} / \mathrm{s}\end{array}$} & \multirow[b]{2}{*}{$\begin{array}{c}\rho_{0} \\
\mathrm{~g} / \mathrm{cm}^{3}\end{array}$} & \multicolumn{4}{|c|}{ Hugoniot } & \multirow[b]{2}{*}{ Buffer } & \multicolumn{4}{|c|}{ Release State } \\
\hline & & & & $\begin{array}{c}\mathrm{U}_{\mathrm{s}} \\
\mathrm{km} / \mathrm{s}\end{array}$ & $\begin{array}{c}\mathrm{u}_{\mathrm{p}} \\
\mathrm{km} / \mathrm{s}\end{array}$ & $\begin{array}{c}\text { Pug, } \\
\text { GPa }\end{array}$ & $\begin{array}{l}\rho_{\text {Hug. }}, \\
\mathrm{g} / \mathrm{cm}^{3}\end{array}$ & & $\begin{array}{c}\mathrm{U}_{\mathrm{s}}, \text { buffer } \\
\mathrm{km} / \mathrm{s}\end{array}$ & $\begin{array}{l}\mathrm{u}_{\text {release }} \\
\mathrm{km} / \mathrm{s}\end{array}$ & $\begin{array}{c}\mathrm{P}_{\text {Telease }} \\
\mathrm{GPa}\end{array}$ & $\begin{array}{l}\rho_{\text {release }} \\
\mathrm{g} / \mathrm{cm}^{3}\end{array}$ \\
\hline LGG-185-Ta & lizardite & $\begin{array}{l}5.684 \\
0.001\end{array}$ & $\begin{array}{l}2.506 \\
0.010\end{array}$ & $\begin{array}{l}10.11 \\
0.10\end{array}$ & $\begin{array}{l}4.360 \\
0.013\end{array}$ & $\begin{array}{c}110.40 \\
0.95\end{array}$ & $\begin{array}{l}4.407 \\
0.042\end{array}$ & $\begin{array}{c}\text { PS } \\
\text { Lexan }\end{array}$ & $\begin{array}{l}8.588 \\
0.166 \\
9.254 \\
0.381\end{array}$ & $\begin{array}{l}6.706 \\
0.123 \\
5.177 \\
0.288\end{array}$ & $\begin{array}{c}2.86 \\
0.11 \\
57.16 \\
5.54\end{array}$ & $\begin{array}{l}3.595 \\
0.075 \\
4.176 \\
0.181\end{array}$ \\
\hline LGG-193-Ta & lizardite & $\begin{array}{l}5.986 \\
0.010\end{array}$ & $\begin{array}{l}2.508 \\
0.010\end{array}$ & $\begin{array}{c}10.33 \\
0.11\end{array}$ & $\begin{array}{l}4.586 \\
0.013\end{array}$ & $\begin{array}{c}118.82 \\
1.12\end{array}$ & $\begin{array}{l}4.510 \\
0.048\end{array}$ & $\begin{array}{c}\text { PS } \\
\text { Lexan }\end{array}$ & $\begin{array}{c}10.060 \\
0.200 \\
9.550 \\
0.380\end{array}$ & $\begin{array}{l}7.794 \\
0.148 \\
5.399 \\
0.288\end{array}$ & $\begin{array}{c}3.90 \\
0.15 \\
61.67 \\
5.74\end{array}$ & $\begin{array}{l}3.213 \\
0.090 \\
4.287 \\
0.178\end{array}$ \\
\hline LGG-186-Ta & lizardite & $\begin{array}{l}6.054 \\
0.009\end{array}$ & $\begin{array}{l}2.503 \\
0.010\end{array}$ & $\begin{array}{l}10.24 \\
0.05\end{array}$ & $\begin{array}{l}4.651 \\
0.011\end{array}$ & $\begin{array}{c}119.20 \\
0.62\end{array}$ & $\begin{array}{l}4.586 \\
0.027\end{array}$ & PS & $\begin{array}{l}9.253 \\
0.109\end{array}$ & $\begin{array}{l}7.198 \\
0.081\end{array}$ & $\begin{array}{l}3.31 \\
0.08\end{array}$ & $\begin{array}{l}3.649 \\
0.051\end{array}$ \\
\hline LGG-194-Ta & lizardite & $\begin{array}{l}6.280 \\
0.010\end{array}$ & $\begin{array}{l}2.491 \\
0.010\end{array}$ & $\begin{array}{l}10.42 \\
0.15\end{array}$ & $\begin{array}{l}4.824 \\
0.016\end{array}$ & $\begin{array}{c}125.21 \\
1.54\end{array}$ & $\begin{array}{l}4.638 \\
0.070\end{array}$ & PS & $\begin{array}{c}10.410 \\
0.400\end{array}$ & $\begin{array}{l}8.052 \\
0.295\end{array}$ & $\begin{array}{l}4.17 \\
0.31\end{array}$ & $\begin{array}{l}3.315 \\
0.179\end{array}$ \\
\hline LGG-204-Pt/Ta & lizardite & $\begin{array}{l}6.202 \\
0.010\end{array}$ & $\begin{array}{l}2.502 \\
0.010\end{array}$ & $\begin{array}{c}10.43 \\
0.17\end{array}$ & $\begin{array}{l}5.399 \\
0.019\end{array}$ & $\begin{array}{c}140.90 \\
1.96\end{array}$ & $\begin{array}{l}5.187 \\
0.109\end{array}$ & PS & $\begin{array}{c}10.550 \\
0.350\end{array}$ & $\begin{array}{l}8.156 \\
0.258\end{array}$ & $\begin{array}{l}4.28 \\
0.28\end{array}$ & $\begin{array}{l}4.026 \\
0.183\end{array}$ \\
\hline LGG-231-Pt/Ta & lizardite & $\begin{array}{l}6.280 \\
0.014\end{array}$ & $\begin{array}{l}2.474 \\
0.004\end{array}$ & $\begin{array}{l}11.06 \\
0.15\end{array}$ & $\begin{array}{l}5.427 \\
0.019\end{array}$ & $\begin{array}{c}148.49 \\
1.70\end{array}$ & $\begin{array}{l}4.857 \\
0.076\end{array}$ & $\begin{array}{c}\text { PS } \\
\text { Lexan }\end{array}$ & $\begin{array}{c}10.580 \\
0.380 \\
10.850 \\
0.500\end{array}$ & $\begin{array}{l}8.178 \\
0.281 \\
6.383 \\
0.379\end{array}$ & $\begin{array}{c}4.30 \\
0.30 \\
82.83 \\
8.73\end{array}$ & $\begin{array}{l}3.871 \\
0.169 \\
4.550 \\
0.275\end{array}$ \\
\hline
\end{tabular}

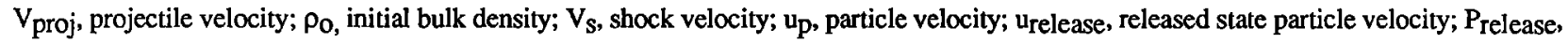
released state pressure; Prelease, released state density. Bottom number of each verticle pair is error value.

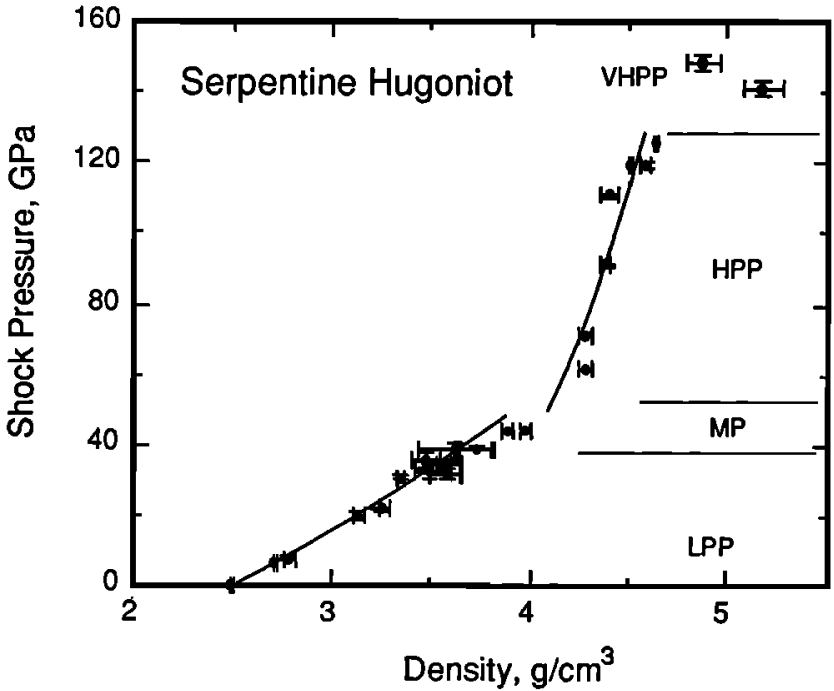

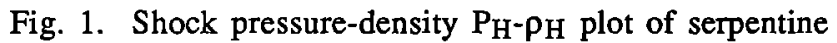
Hugoniot. Data are from Table 3. Solid lines are derived from linear fits to $U_{S}-u_{p}$ results (Figure 2) in the low- and high-pressure regions. Derived parameters are listed in Table 4. LPP, low-pressure phase; MP, mixed phase; HPP, highpressure phase; VHPP, very high presure phase (see text).

and 2 indicate that over the range 0-140 GPa, serpentine exhibits three and perhaps four distinct regimes on the Hugoniot. In Figure 1 these regimes are labeled the "lowpressure phase" (LPP), the "mixed phase", the "high-pressure phase" (HPP), and the "very high pressure phase" (VHPP), respectively. The LPP region lies between 0 and about 40
$\mathrm{GPa}$, the mixed phase region occurs over a narrow pressure interval between approximately 40 and $55 \mathrm{GPa}$, the HPP region lies between approximately 55 and $125 \mathrm{GPa}$. Two shots to pressures greater than $125 \mathrm{GPa}$ suggest the existence of a higher pressure phase assemblage, the VHPP.

Figure 2 is a plot of the shock velocity $U_{S}$ versus particle velocity $u_{p}$ results of this study. The low pressure region exhibits a linear $U_{s}-u_{p}$ relation $\left(U_{s}=C_{o}+s u_{p}\right)$ fit by the parameters $C_{0}=5.294 \pm 0.165 \mathrm{~km} / \mathrm{s}$ and $\mathrm{s}=0.784 \pm 0.098$. Reported bulk sound speed values for serpentine of between 4.65 and $4.95 \mathrm{~km} / \mathrm{s}$ are slightly lower than $\mathrm{C}_{0}$ determined in this study, although reported bulk moduli are consistent with bulk moduli derived in this work [Press, 1966] (see Discussion section). Interpretation of the high pressure region of Figure 2 is more difficult than for the low pressure region. Initially, we defined the high pressure phase region using the four shots that define the dotted line in Figure 2. However, analysis of these four data in terms of normalized pressure and normalized strain (see Discussion section) yields improbably high values of the adiabatic bulk modulus $K_{o s}(\sim 600 \mathrm{GPa})$. Thus we included the following seven data points in the analysis of the high pressure phase: shots numbered 178, 180, 184, 185, 193, 186, and 194 (Table 3). An unweighted linear least squares fit to these data yields $C_{0}=2.405 \pm 0.493 \mathrm{~km} / \mathrm{s}$ and $\mathrm{s}$ $=1.707 \pm 0.118$ (Table 4).

We have examined the possibility that the shock wave was attenuated by longitudinal or lateral rarefactions in the shots that reached the HPP (shots 177 and up, Table 3). Longitudinal attenuation occurs when the rarefaction wave generated at the rear surface (that is, the surface facing the gun breech) of the flyer plate overtakes the shock wave before the shock reaches the free surface of the sample. Lateral 


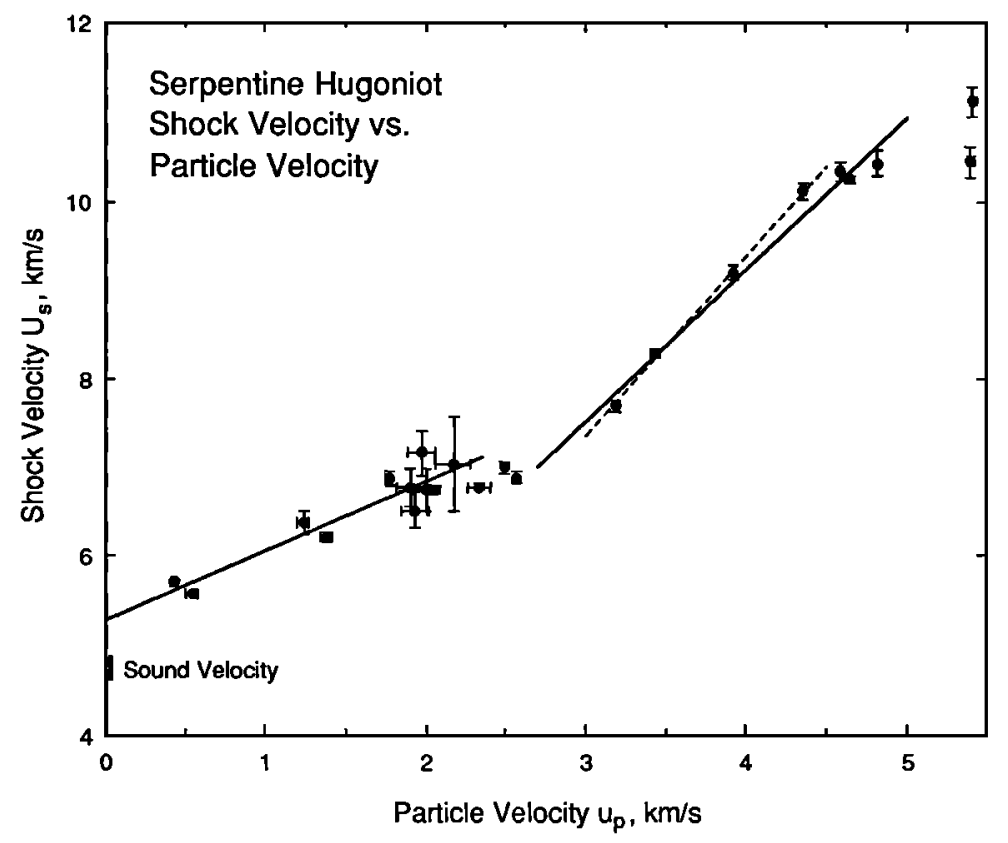

Fig. 2. Shock velocity-particle velocity $U_{\mathbf{s}^{-}} u_{p}$ plot of serpentine Hugoniot. Data are from Table 3. Lines are linear fits to data for low- and high-pressure phase regions. Derived parameters are listed in Table 4. Vertical bar is range of ultrasonic sound speed measurements for serpentine [Press, 1966]. Dashed line is fit to reduced high-pressure phase subset that yields improbable equation of state parameters (see text).

attenuation arises when the shock waves arriving at the sample mirror is completely disrupted by rarefactions from the edge of the sample. In the Appendix we have performed a detailed analysis of the possibility of shock wave attenuation in these experiments. We conclude that longitudinal attenuation cannot have influenced the experimental results. Lateral attenuation could have been a problem in several of the shots, but this conclusion is extremely dependent on the value of the Gruneisen parameter employed in the sound speed calculations. Shot 185 is the shot most likely to have been influenced by lateral attenuation. Rejection of this shot would result in only minor changes in the derived equation of state parameters. Because there are no indications of lateral disruption in the photographic shot records, we feel that the release angle estimates do not justify rejection of any of the shock data. Note also that the two shots reaching the VHPP (shots 204 and 231) are among the least likely to have been influenced by lateral or longitudinal attenuation.

Densities for partially released states are listed in Table 3. The release density is calculated using a straight line approximation to the Riemann integral, and thus represents an upper bound on the density for a given release pressure.and particle velocity [Lyzenga and Ahrens, 1978]. Release paths originating from Hugoniot states at or below about $20 \mathrm{GPa}$ indicate post shock densities up to about $15 \%$ greater than the initial density. Thus for moderate shock compressions the density increase on the Hugoniot is not completely recovered upon isentropic release. Between about 20 and $50 \mathrm{GPa}$ on the Hugoniot, a shock pressure range encompassing part of the LPP region and the mixed phase region, the isentropic release paths are extremely variable in P-p space. Certain paths indicate complete release densities lower than the initial sample density (for example, shot 40-662), suggestive of partial devolatilization upon release, whereas others indicate complete release densities greater than the initial density (for example, shot 40-551). There is no correlation between the onset of the mixed phase regime and complete release density. Impactinduced devolatilization of serpentine occurs at initial shock pressures of 5-6 GPa, corresponding to peak reverberated shock pressures of 17-20 GPa [Lange et al., 1985; Tyburczy et al., 1990]. Figure 3 shows the release paths of the shots that reach the HPP region. The release paths end at densities greater than the initial sample density, and there is a general trend of increasing complete release density with increasing Hugoniot pressure. Steep release paths, from shock pressures greater than those of the onset of phase transformations, have been observed for a number of silicates, including quartz, plagioclase feldspar, and olivine [Grady et al., 1974; Ahrens et al., 1969; Jackson and Ahrens, 1979]. These steep paths have been interpreted as indicating retention of the denser high pressure phase during the release. For the shots reaching the HPP, the maximum complete release densities lie between 3.59 and $3.65 \mathrm{~g} / \mathrm{cm}^{3}$. Accordingly, we have chosen 3.6 $\mathrm{g} / \mathrm{cm}^{3}$ as the initial density of the HPP in our equation of state fitting calculations below. Complete release densities for the VHPP shots are even greater, $3.8-4.0 \mathrm{~g} / \mathrm{cm}^{3}$.

\section{Discussion}

The shock results are used to obtain the equation of state parameters $K_{o s}$ and $K^{\prime}$, the zero pressure adiabatic bulk modulus and its first pressure derivative, for the third-order Eulerian finite strain (Birch-Murnaghan) equation of state for both the LPP and HPP of serpentine. The Hugoniot pressure $P_{H}$ can be written

$$
P_{H}=\frac{\left\{P_{S}-(\gamma / V)\left[E_{S}+E_{t r}\right]\right\}}{\left\{1-(\gamma / V)\left(V_{\infty}-V\right) / 2\right\}}
$$




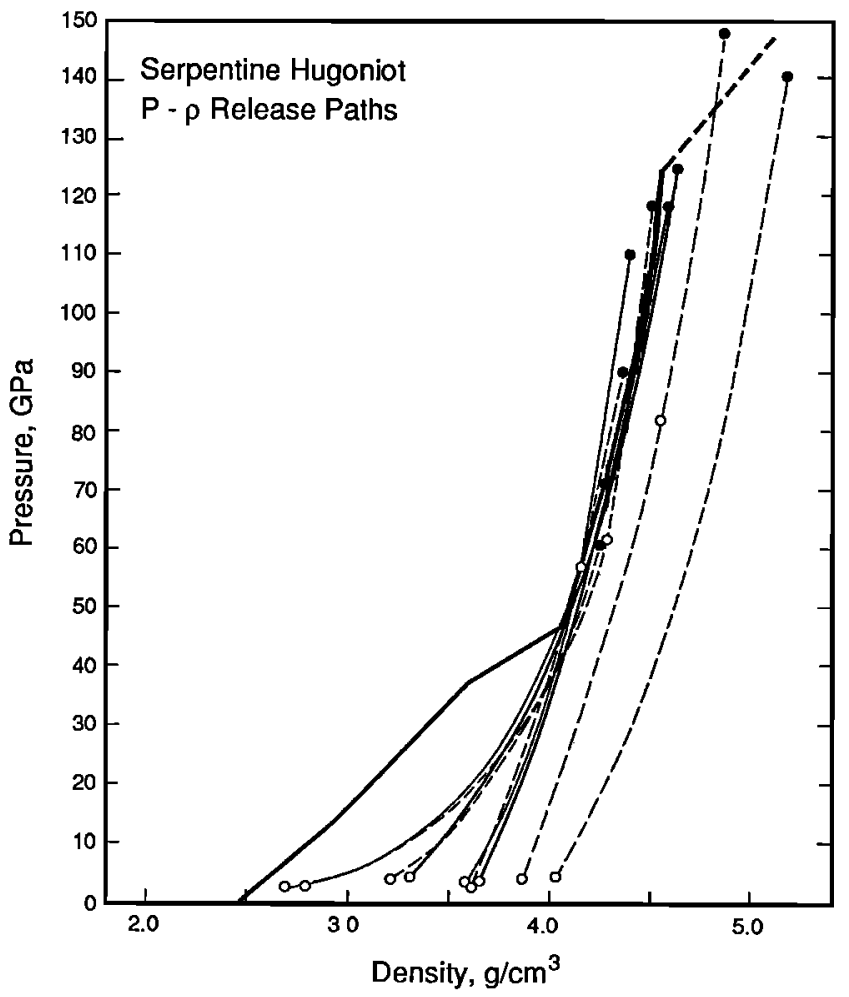

Fig. 3. Isentropic release paths in the pressure-density P-p plane. Solid symbols are Hugoniot data; open symbols are partial release states. Data are from Table 3.

with

$$
E_{s}=-\int_{02}^{v} P_{s} d V
$$

and

$$
\gamma=\gamma_{0}\left(\frac{V}{V_{0}}\right)^{n}
$$

where $P_{S}$ is the pressure on the isentrope at volume $V, \gamma$ is the Gruneisen parameter, $V$ is the Hugoniot volume, $E_{S}$ is the internal energy on the isentrope at volume $V, E_{t r}$ is the energy of transition to a higher pressure polymorph, $\mathrm{V}_{\infty}$ is the initial sample volume, $\mathrm{V}_{\mathrm{O} 2}$ is the zero-pressure volume of the high pressure phase, and $\gamma_{0}$ and $n$ are constants [McQueen et al., 1970; Ahrens, 1979]. The isentrope can be expressed as a normalized pressure F'HS that is a polynomial in the Eulerian strain $f$

$$
f=\frac{1}{2}\left(\left(\frac{V_{0}}{V}\right)^{2 / 3}-1\right)
$$

Following Heinz and Jeanloz [1984] (see also Ahrens and Jeanloz [1987] and Jeanloz [1989]) $F_{H S}^{\prime}$ can be expressed as follows:

$$
F_{H S}^{\prime}=F_{H S}+\Delta F_{t r}=K_{O S}\left(1-2 \xi_{s} f_{3 H}+\ldots\right)
$$

with

$$
F_{H S}=P_{H} \frac{\left(1-\gamma\left(V_{\infty} / V-1\right) / 2\right)}{\left([1+f(2-1.5 \gamma)]\left[3 f V_{o} / V\right]\right)}
$$

$$
\begin{array}{r}
\Delta F_{\mathrm{tr}}=\frac{E_{\mathrm{tr}}}{\mathrm{V}_{0}} \frac{\gamma}{(3 f[1+f(2-1.5 \gamma)])} \\
\mathrm{f}_{3 \mathrm{H}}=\mathrm{f} \frac{[1+\mathrm{f}(2-\gamma)]}{[1+\mathrm{f}(2-1.5 \gamma)]}
\end{array}
$$

and

$$
\xi_{s}=3\left(4-K^{\prime}\right) / 4
$$

The parameters $F_{H S}^{\prime}, \Delta F_{t r}$, and $f_{3 H}$ are derived from the experimental data, and the parameters $K_{\mathrm{os}}$ and $\mathrm{K}^{\prime}$ (through $\xi_{\mathrm{s}}$ ) are derived from a linear fit to (5). Errors in $F_{H S}^{\prime}$ and $f_{3 H}$ are estimated by propagation of errors in $\mathrm{P}_{\mathrm{H}}$ and $\mathrm{\rho H}_{\mathrm{H}}$ through (5) and $(8)$ using the relations

$$
s^{2}\left(F_{H S}^{\prime}\right)=\left(\frac{\partial F_{H S}^{\prime}}{\partial P_{H}}\right)^{2} s^{2}\left(P_{H}\right)+\left(\frac{\partial F_{H S}^{\prime}}{\partial f_{3 H}}\right)^{2} s^{2}\left(f_{3 H}\right)
$$

and

$$
s^{2}\left(f_{3 H}\right)=\left(\frac{\partial f_{3 H}}{\partial V_{H}}\right)^{2} s^{2}\left(V_{H}\right)+\left(\frac{f_{3 H}}{\partial V_{\infty}}\right)^{2} s^{2}\left(V_{\infty}\right)
$$

in which $s\left(F_{H S}^{\prime}\right), s\left(f_{3 H}\right), s\left(P_{H}\right), s\left(V_{H}\right)$, and $s\left(V_{\infty}\right)$ are the estimated errors in $F_{H S}^{\prime}, f_{3 H}, P_{H}, V_{H}$, and $V_{\infty}$, respectively. The partial derivatives in (10) and (11) are evaluated analytically [Heinz and Jeanloz, 1984].

Low-pressure phase. For the serpentine LPP, we assume $\mathrm{E}_{\mathrm{tr}}=0$ and $\mathrm{V}_{\mathrm{o} 2}=\mathrm{V}_{\infty}$. $\gamma_{\mathrm{o}}$ is determined using the relation

$$
\gamma=\alpha \mathrm{K}_{\mathrm{s}} / \rho \mathrm{C}_{\mathrm{p}}
$$

in which $\alpha$, the thermal expansion coefficient, is estimated to be $24 \times 10^{-6} \mathrm{~K}^{-1}$ [Press, 1966], $\mathrm{K}_{\mathrm{s}}=63.5 \mathrm{GPa}$ is obtained below, and $\mathrm{C}_{\mathrm{p}}$ at $\mathrm{STP}$ is $0.97 \mathrm{~J} / \mathrm{g} \cdot \mathrm{K}$ [Berman et al., 1985], yielding a zero-pressure $\gamma_{0}$ of 0.51 . The moduli $K_{0 s}$ and $K^{\prime}$ for the LPP determined using these relations are insensitive to the values of $\gamma_{0}$ and $n$ used. Figure 4 is a plot of the normalized pressure $F_{H S}^{\prime}$ versus strain $f_{3 H}$ for the low pressure phase. An unweighted linear least squares fit of (5) to the experimental data yields $\mathrm{K}_{\mathrm{OS}}=63.5 \pm 3.5 \mathrm{GPa}$ and $\mathrm{K}^{\prime}=$ $2.77 \pm 0.34$. Our derived equation of state parameters for the LPP of shocked serpentine are summarized in Table 4. The value of $\mathrm{CV}$ reported in Table 4 of $1.1 \mathrm{~J} / \mathrm{g} \cdot \mathrm{K}$ is a value averaged over the temperature interval $298-500 \mathrm{~K}$ using the polynomial formulation of $C_{p}$ as a function of temperature of Berman et al. [1985].

The properties of the serpentine LPP appear to be somewhat unusual. Ultrasonic determinations of $\mathrm{K}_{\mathrm{OS}}$ lie between 56 and 68 GPa [Press, 1966]; the shock wave results are in good agreement with this previous work. However, $\mathrm{C}_{0}=5.290 \pm$ $0.165 \mathrm{~km} / \mathrm{s}$ is approximately $10 \%$ higher than reported bulk sound speeds of $4.65-4.95 \mathrm{~km} / \mathrm{s}$ for several serpentines [Press, 1966]. The velocity-density-composition systematics of serpentine are not well known, but the magnitude of the observed discrepancy is greater than can be reasonably accounted for by $\mathrm{Mg}$ content. For comparison, a $10 \%$ decrease in bulk sound velocity of pyroxene or olivine requires an Fe content change of 50-70 mol \% [Jeanloz and Thompson, 


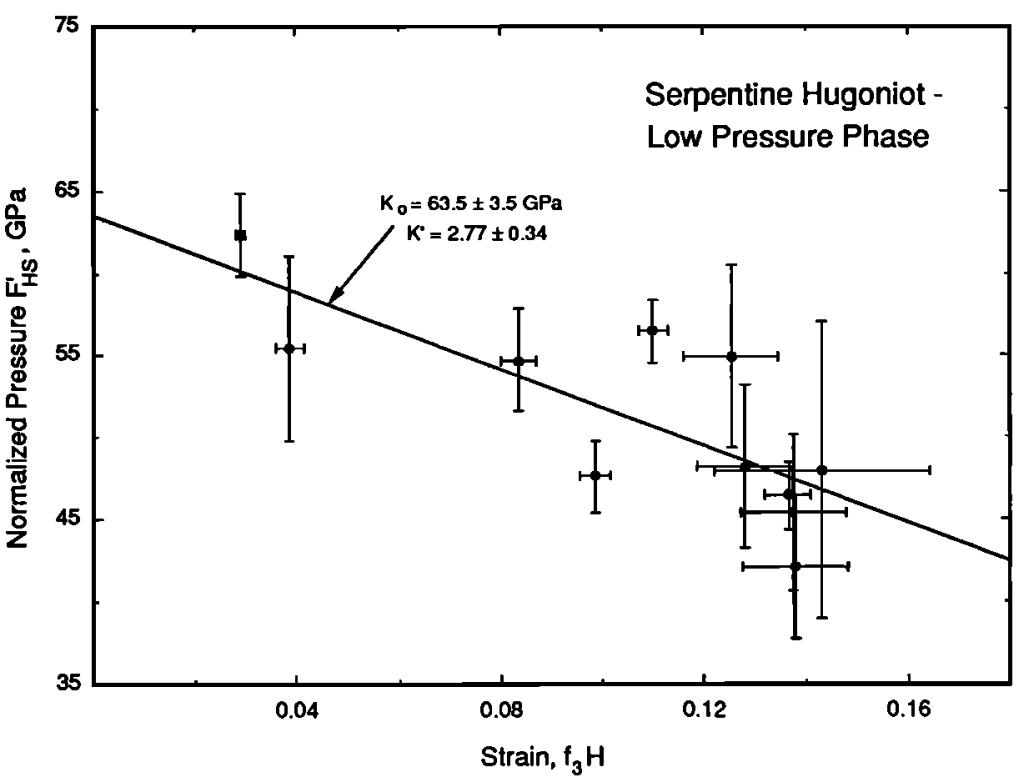

Fig. 4. Normalized pressure F'HS versus normalized strain $f_{3 H}$ plot for serpentine low-pressure phase. Derived fitting parameters are listed in Table 4.

TABLE 4. Derived Equation of State Parameters for Serpentine

\begin{tabular}{|c|c|c|c|}
\hline & $\begin{array}{c}\text { Low-Pressure } \\
\text { Phase }\end{array}$ & \multicolumn{2}{|c|}{$\begin{array}{l}\text { High- Pressure } \\
\text { Phase }\end{array}$} \\
\hline$\rho_{0 o}, \mathrm{~g} / \mathrm{cm}^{3}$ & & \multicolumn{2}{|c|}{$2.50 \pm 0.02$} \\
\hline$\rho_{0}, \mathrm{~g} / \mathrm{cm}^{3}$ & $2.50 \pm 0.02$ & \multicolumn{2}{|c|}{3.60} \\
\hline $\mathrm{C}_{0}, \mathrm{~km} / \mathrm{s}$ & $5.290 \pm 0.165$ & \multicolumn{2}{|c|}{$2.405 \pm 0.493$} \\
\hline $\mathbf{s}$ & $0.784 \pm 0.098$ & \multicolumn{2}{|c|}{$1.707 \pm 0.118$} \\
\hline$\gamma_{0}$ & 0.51 & \multicolumn{2}{|c|}{1.0} \\
\hline $\mathrm{n}$ & 1.0 & \multicolumn{2}{|c|}{1.5} \\
\hline $\mathrm{CV}, \mathrm{J} / \mathrm{g} \cdot \mathrm{K}$ & 1.1 & \multicolumn{2}{|c|}{1.6} \\
\hline $\mathrm{E}_{\mathrm{tr}}, \mathrm{J} / \mathrm{g}$ & & 100 & 1000 \\
\hline $\mathrm{K}_{\mathrm{os}}, \mathrm{GPa}$ & $63.5 \pm 3.5$ & $196 \pm 72$ & $220 \pm 71$ \\
\hline $\mathbf{K}^{\prime}$ & $2.77 \pm 0.34$ & $5.90 \pm 3.22$ & $5.16 \pm 2.81$ \\
\hline
\end{tabular}

1983]. Furthermore, $K^{\prime}=2.77 \pm 0.34$ is a rather low value for this parameter. Assuming that $\mathrm{K}^{\prime}=4.0$ would yield $\mathrm{K}_{\mathrm{os}}=$ $51 \mathrm{GPa}$ and $\mathrm{C}_{0}=4.5 \mathrm{~km} / \mathrm{s}$, but this is not a reasonable representation of the data (see Figure 4). Values of complete release density greater than initial density (Table 3 ) suggest at least partial transformation to a higher-pressure assemblage.

The serpentine LPP may represent transformation under shock to an amorphous phase. Meade and Jeanloz [1989, 1991] have reported amorphization without dehydration in serpentine under static compression at pressures between 6 and $25 \mathrm{GPa}$ and temperatures up to $900 \mathrm{~K}$. Glassy regions were observed in serpentine recovered from shock to pressures greater than $25 \mathrm{GPa}$ [Lambert and Lange, 1984]. $\mathrm{K}_{\mathrm{Os}}$ and $\mathrm{K}^{\prime}$ for glasses ranging in composition from basaltic to rhyolitic were measured ultrasonically to $10 \mathrm{kbar}$ by Meister et al. [1980]. The values range from $38 \mathrm{GPa}$ and -1.83 , respectively, for obsidian glass to $63 \mathrm{GPa}$ and 2.09 for basaltic glass and vary linearly with $\mathrm{SiO}_{2}$. The $\mathrm{K}_{\mathrm{os}}$ and $\mathrm{K}$ values for serpentine determined from these shock experiments are consistent with the linear trends in $\mathrm{K}_{\mathrm{os}}$ and $\mathrm{K}^{\prime}$ with $\mathrm{SiO}_{2}$ content observed by Meister et al. [1980].

High-pressure phase. Equation of state parameters are calculated for the HPP in the same manner as for the LPP. The transition energy terms must be included in (1) and (5). However, the values of $E_{t r}, \gamma_{0}, n$, and $\rho_{02}$, the zero-pressure density of the high-pressure phase, are not well constrained. We assume that $\gamma_{0}=1.0$ and $n=1.5$, values that are representative of values obtained for a variety of high-pressure minerals [Jeanloz and Thompson, 1983; Watt and Ahrens, 1983]. $E_{t r}$ is varied between 100 and $1000 \mathrm{~J} / \mathrm{g}$; equation of state parameters were calculated for both values. $E_{t r}$ for the breakdown of serpentine to oxides at STP is about $600 \mathrm{~J} / \mathrm{g}$ [Robie et al., 1978]. The zero-pressure density $\rho_{02}$ was varied between 3.3 and $4.0 \mathrm{~g} / \mathrm{cm}^{3}$. Reasonable values of $\mathrm{K}^{\prime}$, that is, values between 2.5 and 7.5 , were obtained only for values of $\rho_{02}$ between 3.5 and $3.8 \mathrm{~g} / \mathrm{cm}^{3}$. Figure 5 is a normalized pressure-normalized strain $\mathrm{F}_{\mathrm{HS}}-\mathrm{f}_{3 \mathrm{H}}$ plot for the serpentine HPP calculated using $\rho_{\mathrm{o} 2}=3.6 \mathrm{~g} / \mathrm{cm}^{3}$ and $\mathrm{E}_{\mathrm{tr}}=$ $1000 \mathrm{~J} / \mathrm{g}$. Values of $p_{02}$ of $3.6 \mathrm{~g} / \mathrm{cm}^{3}$ resulted in values of $\mathrm{K}_{\mathrm{OS}}$ of $196 \pm 72$ and $220 \pm 71 \mathrm{GPa}$ and values of $\mathrm{K}^{\prime}$ of $5.90 \pm$ 3.22 and $5.16 \pm 2.81$ for values of $E_{t r}=100$ and $1000 \mathrm{~J} / \mathrm{g}$, respectively. These values represent our preferred range of values for these parameters and are listed in Table 4. Constraining $K^{\prime}$ to equal 4 yields $K_{o s}=249 \pm 26 \mathrm{GPa}$ (for $p_{0}$ $=3.6 \mathrm{~g} / \mathrm{cm}^{3}$ and $E_{t r}=1000 \mathrm{~J} / \mathrm{g}$ ). In addition to experimental error and variation in initial density of the samples, a fundamental problem of extracting $\mathrm{K}_{\mathrm{OS}}$ and $\mathrm{K}^{\prime}$ for the HPP 


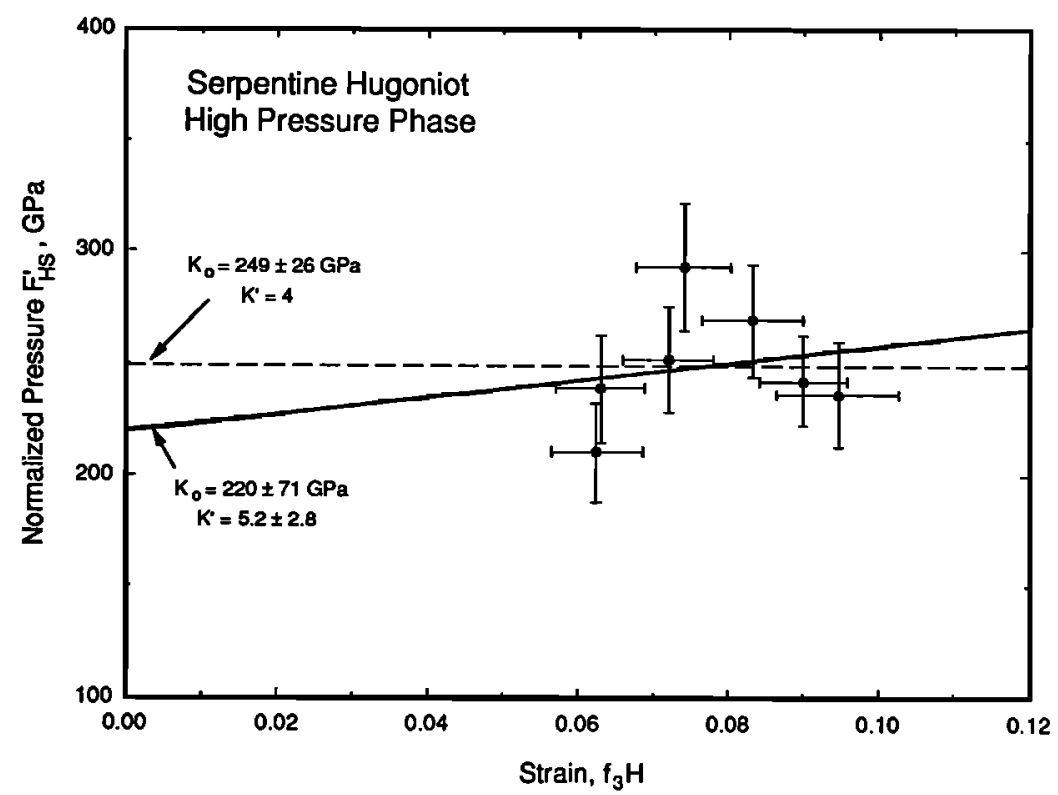

Fig. 5. Normalized pressure F'HS versus normalized strain $f_{3 H}$ plot for serpentine high-pressure phase with $\rho_{02}=3.6 \mathrm{~g} / \mathrm{cm}^{3}$ and $E_{t r}=1000 \mathrm{~J} / \mathrm{g}$. Derived fitting parameters are listed in Table 4 .

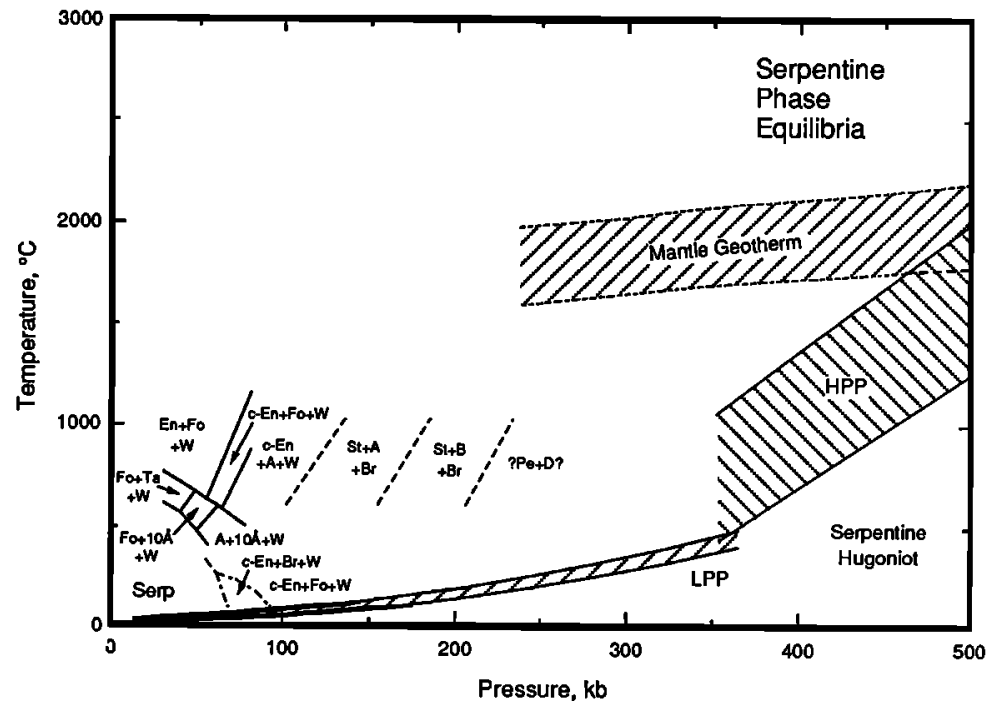

Fig. 6. Serpentine pressure-temperature phase diagram in relation to the serpentine Hugoniot and the mantle geotherm. Mineral abbreviations and chemical formulas are given in Table 5. Solid phase boundaries are from Yamamoto and Akimoto [1977] and Liu [1986]; short-dashed phase boundaries are from Liu [1986, 1987]; dash-dot boundaries were calculated using thermodynamic parameters of Brown et al. [1988]. Range of temperatures on the serpentine LPP Hugoniot calculated using parameters from Table 4 with $\gamma_{o}$ varied a factor of 2 greater and lower than listed. Range of temperatures for serpentine HPP was calculated using parameters in Table 4. Mantle geotherm is bounded by geotherms from Stacey [1977] and Brown and Shankland [1981].

lies in the fact that the HPP assemblage exists over a very narrow range of density (or strain); $f_{3 H}$ ranges only from 0.06 to 0.10 for the HPP (Figure 5).

We address the question of the specific phases present in the serpentine HPP by considering three lines of evidence: (1) existing knowledge of the high pressure P-T phase diagram of serpentine and its relationship to the Hugoniot, (2) release paths and complete release densities determined in this study, and (3) calculated Hugoniots constructed from mixed oxides with or without free water. Figure 6 shows the serpentine phase diagram compiled from the experimental work of Yamamoto and Akimoto [1977], Liu [1986, 1987], and Finger et al. [1989], and the low pressure thermodynamic model of Berman and coworkers [Berman, 1985; Brown et al., 1988]. Table 5 lists the mineral phases of Figure 6 along with their chemical formulas and room temperature, room pressure (STP) densities. Temperatures on the serpentine Hugoniot were calculated using the relation 
TABLE 5. Name, Composition, and Density at Room Temperature and Pressure of Mineral Phases Shown in Figure 11

\begin{tabular}{|c|c|c|c|}
\hline Symbol & Name & Composition & $\begin{array}{l}\text { Density, } \\
\mathrm{g} / \mathrm{cm}^{3}\end{array}$ \\
\hline $\mathrm{Pe}$ & periclase & $\mathrm{MgO}$ & 3.584 \\
\hline St & stishovite & $\mathrm{SiO}_{2}$ & 4.287 \\
\hline W & water & $\mathrm{H}_{2} \mathrm{O}$ & 0.997 \\
\hline Fo & forsterite & $\mathrm{Mg}_{2} \mathrm{SiO}_{4}$ & 3.214 \\
\hline$\beta$ & modified spinel & $\mathrm{Mg}_{2} \mathrm{SiO}_{4}$ & 3.467 \\
\hline En & enstatite & $\mathrm{MgSiO}_{3}$ & 3.204 \\
\hline c-En & clino-enstatite & $\mathrm{MgSiO}_{3}$ & 3.204 \\
\hline $\mathrm{Gt}$ & garnet & $\mathrm{MgSiO}_{3}$ & 3.518 \\
\hline Ilm & ilmenite & $\mathrm{MgSiO}_{3}$ & 3.815 \\
\hline $\mathrm{Pv}$ & perovskite & $\mathrm{MgSiO}_{3}$ & 4.083 \\
\hline $\mathrm{Br}$ & brucite & $\mathrm{Mg}(\mathrm{OH})_{2}$ & 2.367 \\
\hline Serp & serpentine & $\mathrm{Mg}_{3} \mathrm{Si}_{2} \mathrm{O}_{5}(\mathrm{OH})_{4}$ & 2.50 \\
\hline $\mathrm{Ta}$ & talc & $\mathrm{Mg}_{3} \mathrm{Si}_{4} \mathrm{O}_{10}(\mathrm{OH})_{2}$ & 2.788 \\
\hline $10 \AA$ & 10 Ä-Phase & $\begin{array}{l}\mathrm{Mg}_{3} \mathrm{Si}_{4} \mathrm{O}_{10}(\mathrm{OH})_{2} \\
\cdot 2 \mathrm{H}_{2} \mathrm{O}\end{array}$ & 2.65 \\
\hline A & phase $A$ & $\mathrm{Mg}_{7} \mathrm{Si}_{2} \mathrm{O}_{8}(\mathrm{OH})_{6}$ & 2.95 \\
\hline B & phase $B$ & $\mathrm{Mg}_{12} \mathrm{Si}_{4} \mathrm{O}_{19}(\mathrm{OH})_{2}$ & 3.37 \\
\hline $\mathrm{D}$ & phase D & $\mathrm{MgSiO}_{2}(\mathrm{OH})_{2}$ & $?$ \\
\hline Anh B & anhydrous B & $\mathrm{Mg}_{14} \mathrm{Si}_{5} \mathrm{O}_{24}$ & 3.435 \\
\hline
\end{tabular}

Data from Yamamoto and Akimoto [1977], Jeanloz and Thompson [1983], Liu [1986, 1987], and Finger et al. [1989].

$$
T_{H}=T_{0} \exp \left(-\int_{V_{02}}^{V} \frac{\gamma}{V} d V\right)+\frac{E_{H}-E_{t r}-E_{S}}{C V}
$$

in which $T_{H}$ is the Hugoniot temperature and $T_{0}$ is the initial temperature. Calculated serpentine HPP Hugoniot temperatures are also plotted in Figure 6 using the parameters listed in Table 4. For the LPP, the temperature range shown represents a factor of 2 variation in $\gamma_{0}$. For the HPP, the temperature range shown represents the range calculated using each of the two sets of parameter values in Table 4; the larger value of $E_{t r}$ results in a lower Hugoniot temperature.

The LPP serpentine Hugoniot lies at temperatures much lower than those of the existing phase equilibrium experiments. Thermodynamic model calculations that do not include the recently discovered hydrous phases indicate that serpentine would break down to clinoenstatite $\left(\mathrm{MgSiO}_{3}\right)$ plus forsterite $\left(\mathrm{Mg}_{2} \mathrm{SiO}_{4}\right)$ plus free water at a pressure of approximately $70-90 \mathrm{kbar}$ on the Hugoniot. Extrapolation of experiments results performed in the temperature range 700$1000^{\circ} \mathrm{C}$ [Liu, 1986,1987$]$ indicates that a number of hydrous phases, among them brucite, phase A, phase $B$, and possibly phase D (Table 5) could be stable on the LPP Hugoniot. The HPP Hugoniot, and the lower mantle of the Earth, may exist in the poorly constrained Pe $+\mathrm{D}$ field, according to Liu's experiments. The existing experimental data are insufficient to predict whether the serpentine HPP represents decomposition to a mineral assemblage containing free water or is an assemblage that contains hydrous oxides or silicates.

The maximum complete release densities for samples shocked into the HPP field are about $3.6 \mathrm{~g} / \mathrm{cm}^{3}$, indicating retention of the high-pressure mineral assemblage on release. STP densities of mineral assemblages of serpentine stoichiometry are listed in Table 6 . The only assemblage that is suggested to have a zero-pressure density as great as even $3.5 \mathrm{~g} / \mathrm{cm}^{3}$ is the periclase plus phase $\mathrm{D}(\mathrm{Pe}+\mathrm{D})$ assemblage. Thus the release path results suggest that the serpentine HPP assemblage contains Phase D or other as yet unreported ultra high pressure hydrous phases rather than phases A or B.

TABLE 6. Density at Room Temperature and Pressure of Mineral Assemblages Having Serpentine Stoichiometry Possibly Found on the Serpentine Hugoniot

\begin{tabular}{lc}
\hline Assemblage & $\begin{array}{c}\text { Zero-Pressure } \\
\text { Density, } \mathrm{g} / \mathrm{cm}^{3}\end{array}$ \\
\hline $\mathrm{Fo}+\mathrm{En}+\mathrm{W}$ & 2.49 \\
$\mathrm{c}-\mathrm{En}+\mathrm{Br}+\mathrm{W}$ & 2.63 \\
$\mathrm{Pe}+\mathrm{St}+\mathrm{W}$ & 2.83 \\
$\mathrm{Pv}+\mathrm{Pe}+\mathrm{W}$ & 2.88 \\
$\mathrm{~A}+\mathrm{Br}+\mathrm{St}$ & 3.06 \\
$\mathrm{AnhB}+\mathrm{St}+\mathrm{Br}$ & 3.07 \\
$\mathrm{~B}+\mathrm{Br}+\mathrm{St}$ & 3.08 \\
$\mathrm{Pe}+\mathrm{St}+\mathrm{Br}$ & 3.13 \\
$\mathrm{Pv}+\mathrm{St}+\mathrm{Br}$ & 3.16 \\
$\mathrm{Pe}+\mathrm{D}$ & $? 3.5$ \\
\end{tabular}

See Table 5 for mineral abbreviations.

Because of the uncertainty in the phase assemblage of the serpentine HPP, we examine the possibility that the serpentine HPP represents a mixture of silicates or oxides plus water by constructing mixed phase Hugoniots based on Hugoniot equations of state for the constituent oxides. We consider two alternative HPP mixtures: a $\mathrm{MgSiO}_{3}$ perovskite plus $\mathrm{MgO}$ plus $\mathrm{H}_{2} \mathrm{O}$ mixture (Serp $=2 \mathrm{Pv}+\mathrm{Pe}+2 \mathrm{H}_{2} \mathrm{O}$ ) and a brucite $\mathrm{Mg}(\mathrm{OH})_{2}$ plus periclase $\mathrm{MgO}$ plus stishovite $\mathrm{SiO}_{2}$ mixture $\left(\mathrm{Serp}=2 \mathrm{Br}+\mathrm{Pe}+2 \mathrm{SiO}_{2}\right)$. The model Hugoniots are constructed by first computing a mixed solid oxide Hugoniot using Voight-Reuss-Hill averages of individual oxide bulk moduli [Watt et al., 1976; Watt and Ahrens, 1983]. The mixed oxide Hugoniot is combined with the $\mathrm{H}_{2} \mathrm{O}$ Hugoniot $\left(\rho_{o}=0.998 \mathrm{~g} / \mathrm{cm}^{3}, C_{o}=2.393 \mathrm{~km} / \mathrm{s}, \mathrm{s}=1.333\right.$ ) [Mitchell and Nellis, 1982] at the same shock pressure by summing the mass fraction weighted specific volumes of the oxide mixture and $\mathrm{H}_{2} \mathrm{O}$

$$
\rho\left(\text { oxide }+\mathrm{H}_{2} \mathrm{O}\right)=\left[\Sigma\left(\mathrm{F}_{\mathrm{i}} / \mathrm{p}_{\mathrm{i}}\right)\right]^{-1}
$$

where $\mathrm{F}_{i}$ is the mass fraction of component $\mathrm{i}\left(\mathrm{H}_{2} \mathrm{O}\right.$ or oxide mix) in serpentine and $p_{i}$ is the component's density. Table 7 summarizes the equation of state parameters used for the individual oxides and oxide mixtures. Figure 7 shows the results of the calculations. The $\mathrm{H}_{2} \mathrm{O}$ and $\mathrm{Pe}+\mathrm{Pv}$ Hugoniots lie at significantly lower and higher densities, respectively, than does the serpentine Hugoniot. The combined $\mathrm{Pe}+\mathrm{Pv}+$ $\mathrm{H}_{2} \mathrm{O}$ and the $\mathrm{Br}+\mathrm{Pe}+\mathrm{St}$ Hugoniots differ little from each other, and they each reproduce the serpentine HPP Hugoniot reasonably well.

The mixed phase Hugoniots constructed in the above manner are not corrected for temperature differences on the individual (or mixed solid) Hugoniots. To make this correction, we 
TABLE 7. Equation of State Parameters for High-Pressure Mixed Phase Hugoniots

\begin{tabular}{|c|c|c|c|c|c|c|}
\hline & $\mathrm{MgO}$ & $\begin{array}{c}\mathrm{SiO}_{2}^{\mathrm{a}} \\
\text { Stishovite }\end{array}$ & $\begin{array}{c}\mathrm{Mg}(\mathrm{OH}) 2^{\mathrm{b}} \\
\text { Brucite } \\
\end{array}$ & $\begin{array}{c}\mathrm{MgSiO}_{3}^{\mathrm{a}} \\
\text { Perovskite } \\
\end{array}$ & $\begin{array}{c}2 \mathrm{MgSiO}_{3} \\
+\mathrm{MgO} \\
\end{array}$ & $\begin{array}{l}2 \mathrm{Mg}(\mathrm{OH})_{2}+ \\
\mathrm{MgO}+2 \mathrm{SiO}_{2} \\
\end{array}$ \\
\hline$\rho_{\infty}, \mathrm{g} / \mathrm{cm}^{3}$ & 3.584 & 2.65 & 2.38 & 3.22 & 3.258 & 2.619 \\
\hline$\rho_{0}, \mathrm{~g} / \mathrm{cm}^{3}$ & 3.584 & 4.29 & 2.38 & 4.10 & 4.00 & 3.132 \\
\hline $\mathrm{K}_{\mathrm{os}}, \mathrm{GPa}$ & 163 & 316 & 51 & 260 & 238 & 115 \\
\hline $\mathrm{K}^{\prime}$ & 4.1 & 4.0 & 5.0 & 4.0 & 4.0 & 4.5 \\
\hline$\gamma_{o}$ & 1.54 & 1.5 & 1.0 & 1.0 & 1.0 & 1.0 \\
\hline $\mathrm{n}$ & 1.5 & 1.5 & 1.5 & 1.5 & 1.5 & 1.5 \\
\hline $\mathrm{E}_{\mathrm{tr}}, \mathrm{kJ} / \mathrm{g}$ & --- & -- & -- & --- & 1.0 & 1.0 \\
\hline
\end{tabular}

\footnotetext{
b Watt and Ahrens [1983]

Duffy et al. [1991]
}

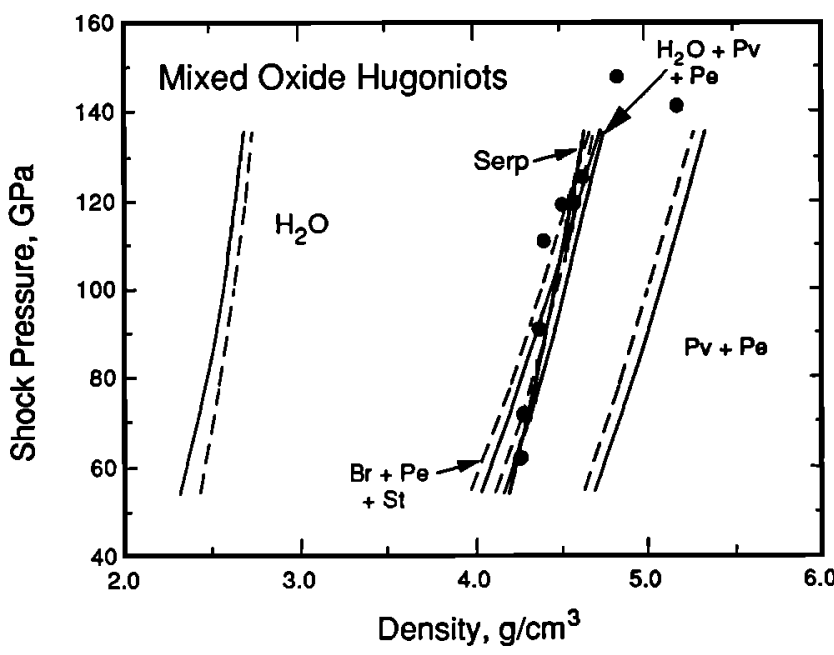

Fig. 7. Pressure-density Hugoniot for serpentine HPP (solid symbols and heavy line) compared to Hugoniots for $\mathrm{H}_{2} \mathrm{O}$ and for mixed oxides. Parameters are from Table 4. Light lines are Hugoniots uncorrected for temperature; dashed lines are Hugoniots corrected to the temperature of the serpentine HPP Hugoniot.

calculated shock temperatures for the $\mathrm{H}_{2} \mathrm{O}$ and for the mixed solid phases. Temperatures for the mixed solids were calculated using (13) and the parameters listed in Table 7. For $\mathrm{H}_{2} \mathrm{O}$, shock temperatures were calculated using the Bakanova equation of state [Bakanova et al., 1976; Ahrens and O'Keefe, 1985]. The Bakanova parameter $\eta$ is defined as

$$
\eta(P)=P(\partial V / \partial E) P
$$

and has been parameterized as follows:

$$
\eta(P)=a_{1}\left[1-\exp \left(a_{2} P\right)\right]+a_{3} P \exp \left(a_{4} P\right)
$$

where $a_{1}=0.07, a_{2}=-0.08463 \mathrm{GPa}^{-1}, \mathrm{a}_{3}=0.044095 \mathrm{GPa}^{-1}$, and $a_{4}=-0.048202 \mathrm{GPa}^{-1}$ [Bakanova et al., 1976]. The Bakanova equations can be employed to determine the temperature and volume on an isentrope according to

$$
T_{s}(P)=T_{0} \exp \int_{P_{o S}}^{P} \frac{\eta}{[1+\eta] P} d P
$$

and

$V_{S}(P)=V_{H}\left(1+\frac{\eta}{2}\right)-\frac{\eta}{P}\left(\int_{O S}^{V_{H}} d V-E_{o s}+E_{o}+\frac{P_{H} V_{0}}{2}\right)$

where $T_{s}(P)$ is the temperature on the isentrope at pressure $P$, $V_{s}$ is the volume on the isentrope at pressure $P, T_{O S}, V_{O S}$, and $E_{o s}$, are the temperature, volume, and internal energy at the foot of the isentrope at pressure $P_{O S}, V_{H}$ is the volume on the Hugoniot at shock pressure $P$, and $E_{o}$ and $V_{o}$ are the internal energy and volume at the foot of the Hugoniot (commonly at STP conditions). The reference pressure for the foot of the isentrope $P_{o s}$ is $5 \mathrm{GPa}$, and $E_{o s}, T_{o s}$, and $V_{o s}$ at $5 \mathrm{GPa}$ are taken from Bakanova et al. [1976]. This equation of state has been shown to successfully reproduce experimentally measured shock temperatures in water to pressures exceeding $80 \mathrm{GPa}$ [Bakanova et al., 1976; Ahrens and O'Keefe, 1985].

Figure 8 shows the calculated Hugoniot temperatures for the serpentine HPP (parameters from Table 4), the oxide mixtures $\mathrm{Pe}+\mathrm{Pv}$ and $\mathrm{Br}+\mathrm{Pe}+\mathrm{St}($ Table 7$)$, and $\mathrm{H}_{2} \mathrm{O}$. The anhydrous mixed oxides have the lowest temperature Hugoniots, $\mathrm{H}_{2} \mathrm{O}$ the highest temperature Hugoniots. At $100 \mathrm{GPa}$, the mixed oxide Hugoniots lie between 2400 and $2800 \mathrm{~K}$, the serpentine HPP Hugoniot is between 4200 and $4800 \mathrm{~K}$, and the water Hugoniot occurs at about $6500 \mathrm{~K}$. The Hugoniot densities of $\mathrm{H}_{2} \mathrm{O}$ and the oxide mixtures adjusted to the temperature of the serpentine Hugoniot are shown as dashed lines in Figure 7. The density corrections for $\mathrm{H}_{2} \mathrm{O}$ were made using the Bakanova equation of state discussed earlier. Density corrections for the oxide mixtures were made using the MieGruneisen equation of state, the parameters in Table 7, and assuming that $C_{V}$ is equal to $3 R$. The effects on bulk density of cooling the $\mathrm{H}_{2} \mathrm{O}$ and heating the $\mathrm{Pv}+\mathrm{Pe}$ Hugoniots cancel almost completely; incorporation of the temperature effects reduce the density of the $\mathrm{H}_{2} \mathrm{O}+\mathrm{Pv}+\mathrm{Pe}$ mixed oxide Hugoniot by less than $0.04 \mathrm{~g} / \mathrm{cm}^{3}$ between 50 and $140 \mathrm{GPa}$. 


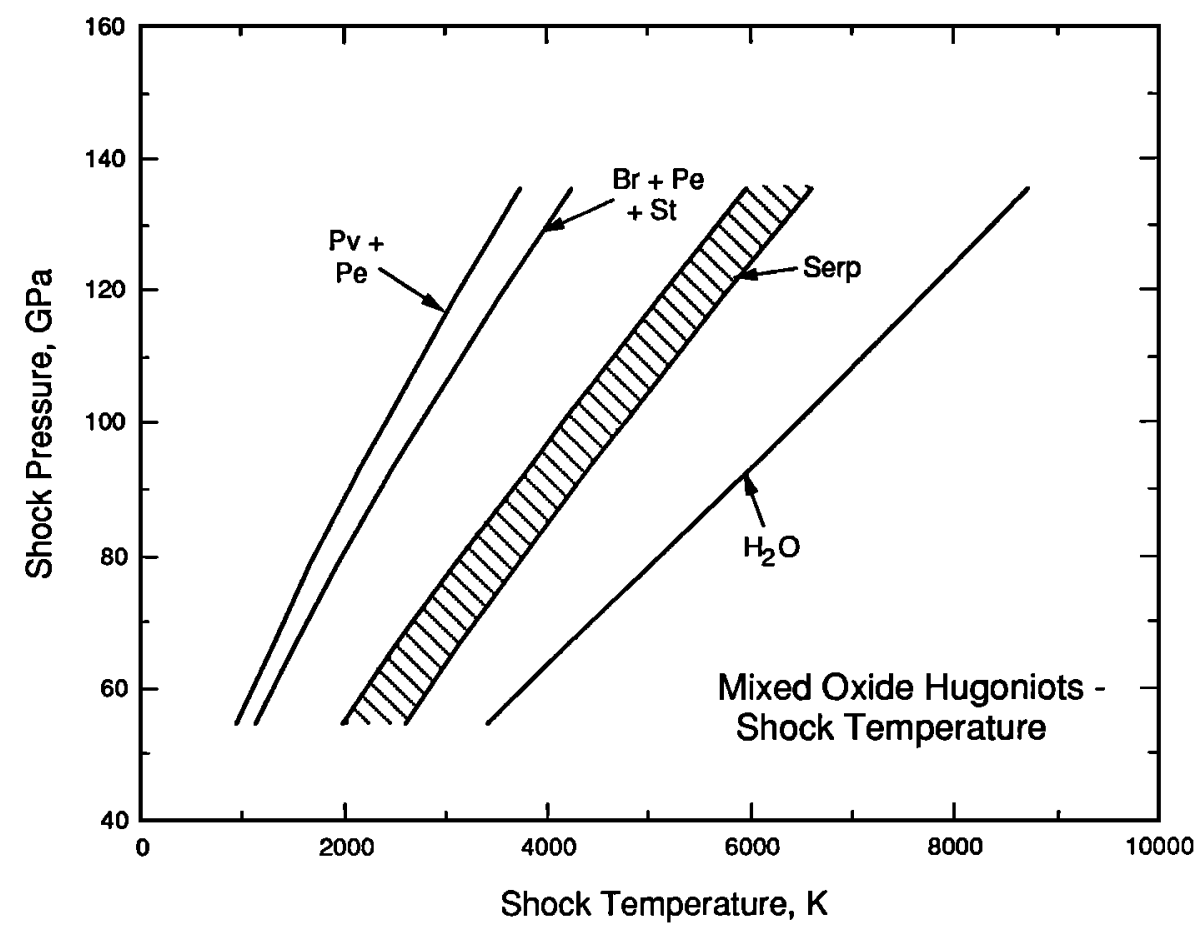

Fig. 8. Calculated shock temperature for serpentine HPP (hatched area) and for $\mathrm{H}_{2} \mathrm{O}$ and mixed oxide Hugoniots.

The temperature-corrected $\mathrm{Br}+\mathrm{Pe}+\mathrm{St}$ mixed oxide Hugoniot is between $0.12 \mathrm{~g} / \mathrm{cm}^{3}$ (at $50 \mathrm{GPa}$ ) and $0.06 \mathrm{~g} / \mathrm{cm}^{3}$ (at 140 $\mathrm{GPa}$ ) lower in density than the uncorrected Hugoniot. The $\mathrm{H}_{2} \mathrm{O}+\mathrm{Pv}+\mathrm{Pe}$ mixed phase Hugoniot matches the experimental serpentine HPP slightly better than does the $\mathrm{Br}+$ $\mathrm{Pe}+\mathrm{St}$ Hugoniot, particularly in the 40-60 GPa range. However, given the assumptions in $\gamma$ and $E_{t r}$, either constructed Hugoniot provides a reasonable fit to the data. Matching the serpentine HPP with a brucite containing mixture is a significant result because brucite undergoes no apparent phase transitions under shock compression to at least $97 \mathrm{GPa}$, although dehydration of brucite cannot be ruled out above 26 GPa [Simakov et al., 1974; Duffy et al., 1991]. Thus modeling the Hugoniot with a brucite-containing mixture suggests incorporation of $\mathrm{H}_{2} \mathrm{O}$ into the crystal structure, that is, existence of a stable hydrous phase. The steep release paths and high zero-pressure density of the HPP suggest an assemblage containing phase $\mathrm{D}$ or another even higherpressure hydrous phase. However, because the serpentine HPP can also be approximated by a free water-containing assemblage, the question of whether the serpentine HPP Hugoniot represents a transformation to a phase assemblage containing a hydrous mineral or represents decomposition to an assemblage containing free $\mathrm{H}_{2} \mathrm{O}$ cannot be answered unambiguously.

The "very high pressure phase" (VHPP) that occurs above $125 \mathrm{GPa}$ on the serpentine Hugoniot (Figures 1 and 2) is more poorly unconstrained than the HPP. Compared with most known high-pressure materials, the $\mathbf{P}_{\mathbf{H}}-\mathrm{P}_{\mathbf{H}}$ curve indicates a very compressible material. A possible explanation is that the serpentine HPP undergoes incongruent melting on the Hugoniot at about $125 \mathrm{GPa}$. Melting on the Hugoniot has been suggested to occur in olivine Fo90 at a shock pressure of about $150 \mathrm{GPa}$ [Furnish and Brown, 1986; Brown et al.,
1987]. Figure 9 is a plot of the olivine Hugoniot data of Furnish and Brown [1986] and McQueen et al. [1967] along with the experimental results of this study. In comparison to the olivine results, the serpentine VHPP data indicate a much larger compression occurring over a narrower pressure range than for the olivine VHPP. Note that the density of the VHPP may be comparable to that of the $2 \mathrm{Pv}+\mathrm{Pe}$ assemblage (Figure 7). However, lacking experiments reaching shock pressures greater than $150 \mathrm{GPa}$, it is not certain that the density of this shot corresponds to that of the completely molten (or transformed) material.

Implications for the lower mantle. Figure 10 shows the Hugoniot density of serpentine compared to Hugoniot densities of Fo90 olivine $(\mathrm{Mg} /(\mathrm{Mg}+\mathrm{Fe})=0.90$ [Brown et al., 1987]), Fo 45 [McQueen et al., 1967], En85 [Trunin et al., 1965], and the lower mantle density-depth curve of the Preliminary Reference Earth Model (PREM) of Dziewonski and Anderson [1981]. The Hugoniot data are not corrected for temperature. The serpentine Hugoniot lies at densities 15-20\% lower than those of the PREM. Uncorrected Fo90 and En85 Hugoniots lie within 5-7\% of the PREM density values; correction for temperature effects brings them into closer agreement with PREM [Watt and Ahrens, 1986].

In this section we estimate the amount of $\mathrm{H}_{2} \mathrm{O}$ (as serpentine HPP) that can be contained in the Earth's mantle consistent with observed density values. A lower mantle model was constructed by summing the mass fraction weighted specific volumes of $\mathrm{Fog}_{0}, \mathrm{Fo}_{45}$, En85, and serpentine HPP using the Hugoniot P-p relations (Figure 10), subject to the constraints of constant bulk atomic $\mathrm{Mg} /(\mathrm{Mg}+\mathrm{Fe})$ and $(\mathrm{Mg}+\mathrm{Fe}) / \mathrm{Si}$ ratios. A density correction of $0.1 \mathrm{~g} / \mathrm{cm}^{3}$ was added to the Hugoniot density of each phase to correct for the higher temperatures of the Hugoniot states relative to the mantle geotherm [Watt and Ahrens, 1986]. In all the following calculations, the 


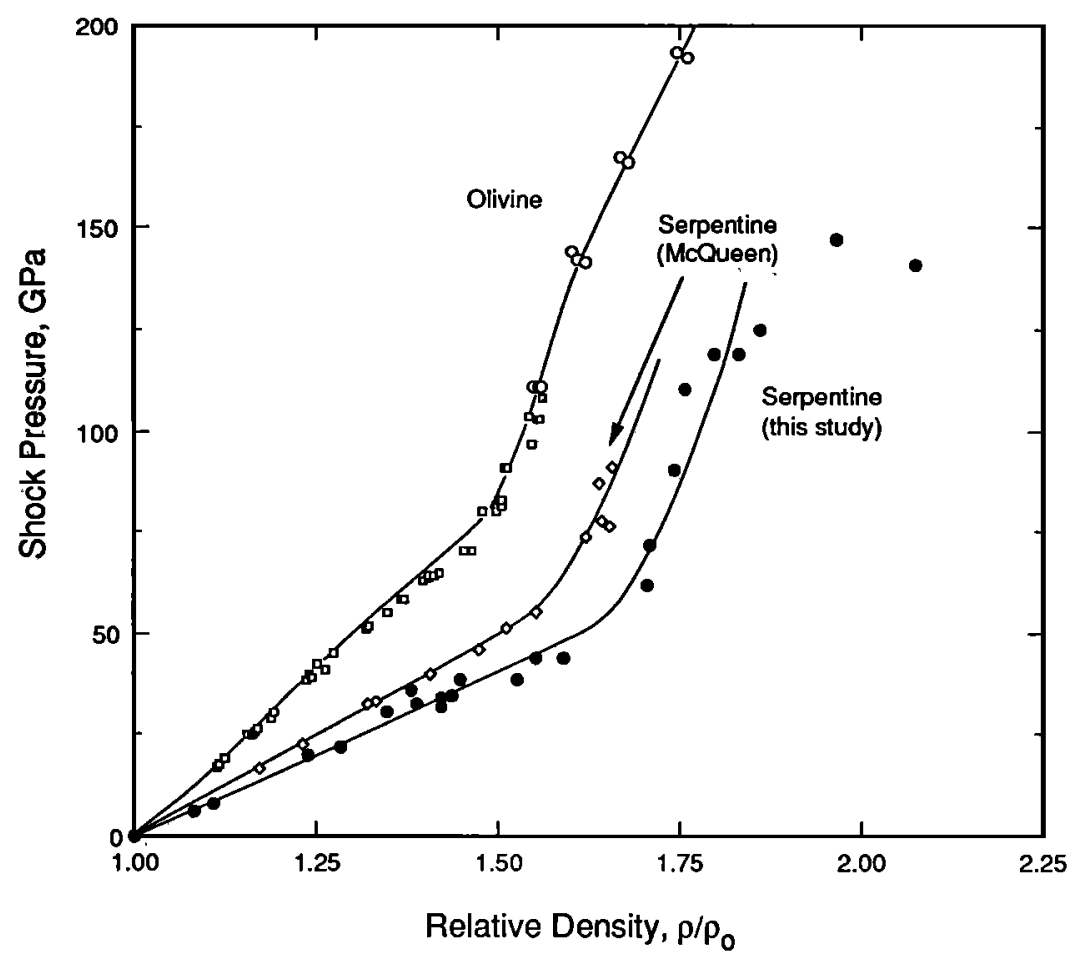

Fig. 9. Hugoniots for olivine Fogo [McQueen et al., 1967; Furnish and Brown, 1986] and serpentine [Marsh, 1980; this study) illustrating the transition to the very high pressure phase.

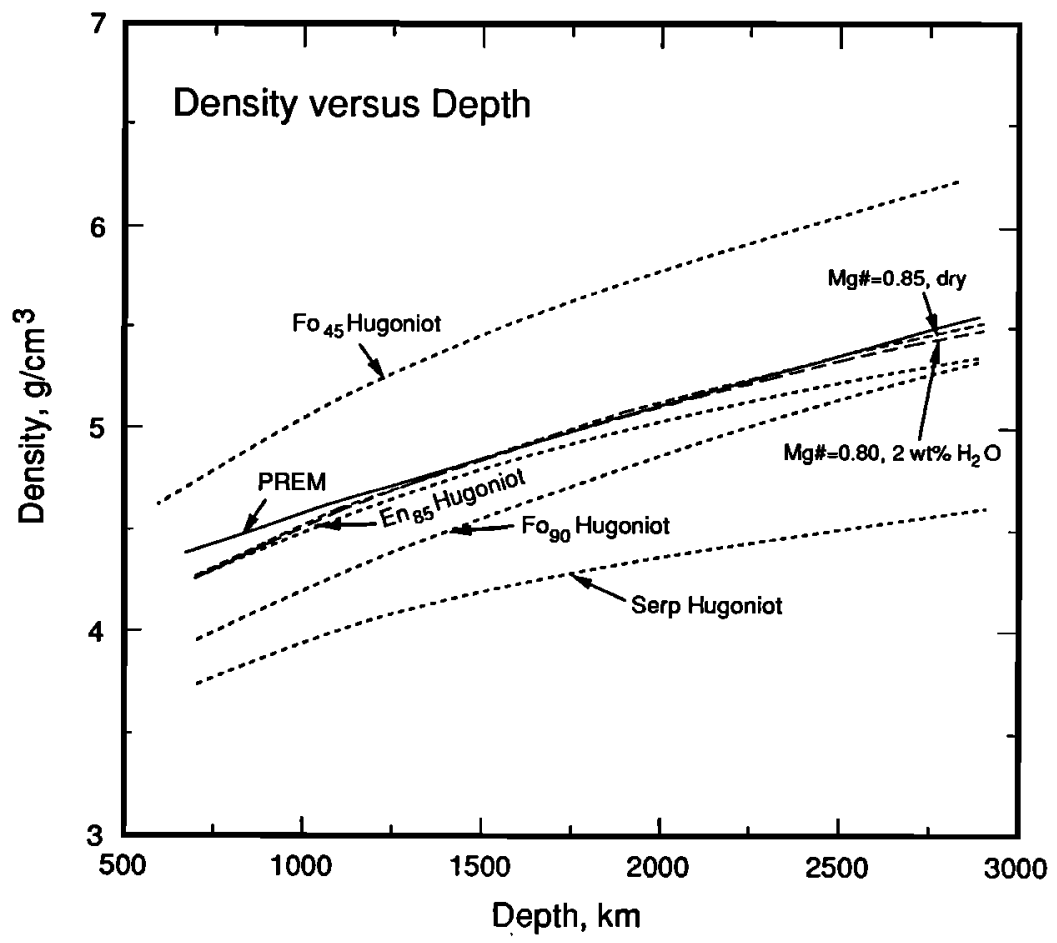

Fig. 10. Density versus depth plot comparing lower mantle density to models with and without $\mathrm{H}_{2} \mathrm{O}$ : solid line, PREM [Dziewonski and Anderson, 1981]; dashed lines, temperature-corrected models (see text); dotted lines are Hugoniots (not temperature corrected) of serpentine high pressure phase (this study), Fo90 [Brown et al., 1987], Fo45 [McQueen et al., 1967], and En85 [Trunin et al., 1965].

$(\mathrm{Mg}+\mathrm{Fe}) / \mathrm{Si}$ ratio was fixed at 1.5 , broadly consistent with estimated bulk mantle values of $\sim 1.4$ [Ringwood, 1975; Anderson, 1989] and equal to the value for serpentine. Errors in density are estimated to be $\pm 0.1 \mathrm{~g} / \mathrm{cm}^{3}$ for the anhydrous phases and $\pm 0.24 \mathrm{~g} / \mathrm{cm}^{3}$ for the serpentine HPP.
Figure 10 also shows two such models compared with the PREM density profile. An anhydrous mantle with $\mathrm{Mg}$ number $=0.85$ provides a good match to the PREM, as does a model with $\mathrm{Mg}$ number $=0.80$ and $2 \mathrm{wt} \% \mathrm{H}_{2} \mathrm{O}$. Thus the presence of small amounts of $\mathrm{H}_{2} \mathrm{O}$ is consistent with density models of 
the Earth's interior. Greater amounts of $\mathrm{H}_{2} \mathrm{O}$ can be incorporated into lower mantle models if the Fe content is correspondingly increased.

Bulk sound speeds can be calculated for serpentine using the Hugoniot results but are very uncertain owing to the uncertainties in $\gamma$. Calculated sound speeds for the serpentine HPP using the parameters in Table 4 are very broadly consistent with lower mantle sound velocities. However, because the Hugoniot sound speeds are poorly constrained, the Hugoniot density results discussed above provide more stringent constraints on the possible $\mathrm{H}_{2} \mathrm{O}$ content of the lower mantle.

The amount of $\mathrm{H}_{2} \mathrm{O}$ in the Earth's lower mantle permitted by the density constraints from shock experiments are well in excess of those assumed in petrological models or predicted by accretion models. The occurrence of $2 \mathrm{wt} \% \mathrm{H}_{2} \mathrm{O}$ in the Earth's lower mantle would constitute a reservoir of approximately $5.9 \times 10^{24}$ g or about 42 times the present mass of the oceans [Ringwood, 1975; Walker, 1977]. 'Estimates of mantle water content based on accretion scenarios lie between about 1 and 10 times the present mass of the oceans. Such estimates are influenced by estimates of the water content of incident planetesimals, solubility of $\mathrm{H}_{2} \mathrm{O}$ in a global magma ocean, surface $\mathrm{H}_{2} \mathrm{O}$ pressure, and mechanisms and rates of planetary escape and recycling of hydrogen [Abe and Matsui, 1985; Liu, 1987; Zahnle et al., 1988; Ahrens et al., 1989; Peacock, 1990]. In addition, it is not certain whether hydrous magnesium silicate minerals exist that are stable to lower mantle pressure-temperature conditions. However, phase B, which contains 2.4 wt $\% \mathrm{H}_{2} \mathrm{O}$ (Table 5), has been suggested as a possible lower mantle water-containing mineral [Finger et al., 1989]. Because melting relations and other relevant phase equilibria for phase B and other hydrous phases are extremely uncertain, we refrain from further speculation on the likelihood or consequences of a water-rich lower mantle. Obtaining tighter constraints on mantle $\mathrm{H}_{2} \mathrm{O}$ content will require determination of high-pressure sound velocities of relevant high-pressure hydrous silicate minerals.

\section{Conclusions}

The shock equation of state of $\mathrm{Mg}$ end-member serpentine to $150 \mathrm{GPa}$ exhibits four distinct regions. Up to about $40 \mathrm{GPa}$, a low pressure phase (LPP) exists. The derived equation of state parameters of the LPP are suggestive of transformation to an amorphous assemblage different from the starting material. Thermodynamic calculations indicate that under equilibrium conditions serpentine would decompose to oxides plus water at conditions below $10 \mathrm{GPa}$ along the Hugoniot. Between 40 and $55 \mathrm{GPa}$ a mixed phase region exists. A high-pressure phase (HPP) occurs between 55 and $125 \mathrm{GPa}$. Preferred equation of state parameters for the HPP are $p_{02}=3.6 \mathrm{~g} / \mathrm{cm}^{3}$, $\mathrm{K}_{\mathrm{os}}=220 \pm 71 \mathrm{GPa}, \mathrm{K}^{\prime}=5.16 \pm 2.81$, and $\mathrm{E}_{\mathrm{tr}}=1000 \mathrm{~J} / \mathrm{g}$. The zero-pressure density of $3.6 \mathrm{~g} / \mathrm{cm}^{3}$, which is indicated by steep release paths as well as equation of state parameter fitting, suggests that phase D or an even higher pressure hydrous phase may be stable on the Hugoniot. However, the serpentine HPP Hugoniot can be modeled as either a mixed oxide assemblage containing free $\mathrm{H}_{2} \mathrm{O}$ or as a hydrous mineral (brucite: $\mathrm{Mg}(\mathrm{OH})_{2}$ ) containing assemblage. Thus the shock equation of state results are inconclusive with regard to the existence of stable hydrous magnesium silicate minerals on the
Hugoniot and at conditions of the Earth's lower mantle. Above $125 \mathrm{GPa}$, a transition to a very compressible phase, possibly a hydrous partial melt, occurs.

The serpentine HPP is $15-20 \%$ less dense than the lower mahtle at equivalent pressures. Models containing 2 wt $\%$ $\mathrm{H}_{2} \mathrm{O}$ (for bulk atomic $\mathrm{Mg} /[\mathrm{Mg}+\mathrm{Fe}]=0.80$ and $[\mathrm{Mg}+\mathrm{Fe}] / \mathrm{Si}=$ 1.5) are consistent with the density of the Earth's lower mantle. Greater amounts of $\mathrm{H}_{2} \mathrm{O}$ can be accommodated into acceptable models with concomitant increases in Fe content. Bulk sound velocities estimated from the shock equation of state are broadly consistent with lower mantle seismic velocities. Thus the high-pressure density and sound speed of an $\mathrm{H}_{2} \mathrm{O}$-rich magnesium silicate compared to the observed seismic properties of the lower mantle permit the existence of several weight percent of water in the lower mantle.

\section{Appendix}

In this Appendix we perform an analysis of lateral and longitudinal attenuation for experiments that reach the HPP region on the serpentine Hugoniot. Longitudinal attenuation occurs when the rarefaction wave generated at the rear surface (the surface facing the gun breech) of the flyer plate overtakes the shock wave before the shock reaches the free surface of the sample. We have calculated the sample free surface arrival times of both the shock wave and the release waves for the high shock pressure experiments using the shock equation of state properties of the serpentine (Table 4). In these experiments, Ta flyers and drivers were used except for shots 204 and 231, in which a Pt flyer was used. The Hugoniot of Ta has been determined to $220 \mathrm{GPa}$ by McQueen et al. [1970] and to $429 \mathrm{GPa}$ by Mitchell and Nellis [1981]. Rarefaction wave velocities have been measured in Ta to $440 \mathrm{GPa}$ with a precision of better than 2\% [Brown and Shaner, 1984]. Melting occurs on the Ta Hugoniot at $295 \mathrm{GPa}$. The Pt Hugoniot has been determined to $680 \mathrm{GPa}$ [Morgan, 1974] (see also Holmes et al. [1989]). The release wave velocities for $\mathrm{Pt}$ are more uncertain than those of Ta. Bulk rarefaction velocities $\mathrm{C}_{\mathrm{H}}$ for $\mathrm{Ta}, \mathrm{Pt}$, and the sample were calculated from the slope of the Hugoniot using the relation

$$
C_{H}=\frac{C_{o}(1-\eta)}{(1-s \eta)^{3 / 2}}\left[1+s \eta\left(1-\frac{\gamma \eta}{1-\eta}\right)\right]^{1 / 2}
$$

in which $\gamma$ is the Gruneisen parameter and $\eta$ is the compression

$$
\eta=\frac{V_{0}-V}{V_{0}}
$$

with $\mathrm{V}$ the volume and $\mathrm{V}_{\mathrm{o}}$ the initial sample volume [McQueen et al., 1967]. The Gruneisen parameter $\gamma$ is given by

$$
\gamma=\gamma_{0}\left(\frac{V}{V_{0}}\right)^{n}
$$

in which $\gamma_{0}$ and $n$ are constants [McQuéen et al., 1970]. For $\mathrm{Ta}$ and $\mathrm{Pt}$ bulk rarefaction velocities were calculated assuming that the product $\gamma_{\rho}$ is a constant ( $\gamma_{0}$ is given in Table 2$)$; for serpentine $\gamma_{0}=1.0$ and $n=1.5$ were employed. Longitudinal wave velocities were calculated for $\mathrm{Pt}$ and the sample assuming that Poisson's ratio $v=0.33$ independent of pressure. These methods have been shown to reproduce 
measured Hugoniot sound speeds to within a few percent for a number of materials [Brown and Shaner, 1984; McQueen et al., 1984; Chhabildas et al., 1988]. If $\mathrm{Pt}$ melts at a Hugoniot pressure of less than $450 \mathrm{GPa}$, the release wave velocity would be at least $15 \%$ lower than that employed in these calculations, further reinforcing our conclusion. The parameters employed for Ta and Pt are listed in Table 2, those employed for the HPP phase of serpentine are listed in Table 4.

Figure A1 is a hypothetical time-Lagrangian distance plot for shot 204, which employed a Pt flyer and Ta driver, assuming that the properties of the sample are those of the serpentine HPP. At time $t=0$, impact occurs and shock waves propagate forward into the Pt driver and rearward into the Ta flyer. At time $t_{1}$ the forward traveling shock wave leaves the Pt driver and enters the sample. At $t_{2}$ the forward traveling shock reaches the free surface of the sample whereupon its arrival would be recorded by the streak camera. At $t_{3}$ the rearward traveling shock reaches the rear surface of the flyer and reflects forward as a rarefaction wave. The rarefaction fan is represented by curves for initial elastic and plastic release. The forward traveling release wave arrives at the free surface at some later time $t_{6}$. For this and all other experiments, the shock wave is calculated to reach the free surface at least 100 ns before the release arrival. Furthermore, the shock arrives at the free surface before the rarefaction arrives at the driversample interface. This conclusion holds even if a very stiff (high sound speed) equation of state is assumed for the serpentine HPP, such as that indicated by the dotted line in
Figure 2. Thus uncertainties in the sample release wave velocity do not affect our conclusion. It is very unlikely that longitudinal attenuation occurred in these experiments.

Lateral attenuation of the shock wave occurs when the region of the shock front that would normally strike the sample mirrors has been entirely disrupted by lateral rarefactions originating at sample edges. The release angle defines the region of the target that is perturbed by lateral rarefactions. The geometry is sketched in Figure A2. The critical target release angle $\theta_{\text {crit }}$ is the release angle for which the entire sample mirror falls just within the perturbed region; it is determined by sample mirror width and sample thickness (Figure A2). Lateral release is a problem if the actual release angle $\theta$ is greater than $\theta_{\text {crit. }}$ Release angles were calculated for the HPP of serpentine using the relation [Al'tshuler et al., 1960]

$$
\tan \theta=\left[\left(\frac{C_{H}}{U_{S}}\right)^{2}-\left(\frac{C_{H}}{C_{L}}\right)^{2}\right]^{1 / 2}
$$

in which $\theta$ is the release angle, $C_{H}$ is the Eulerian sound speed on the Hugoniot (equation (A1)), and $\mathrm{C}_{\mathrm{L}}$ is the Lagrangian sound speed on the Hugoniot $C_{L}=C_{H}\left(V_{d} / V_{H}\right)$, where $V_{H}$ is the volume in the shocked state. Calculated release angles are sensitive to the value of $\gamma$ employed. Figure $A 3$ is a plot of calculated release angle $\theta$ from equation (A4) versus shock pressure for the serpentine high-pressure phase. Also shown are the critical release angles $\theta_{\text {crit }}$ determined from the sample

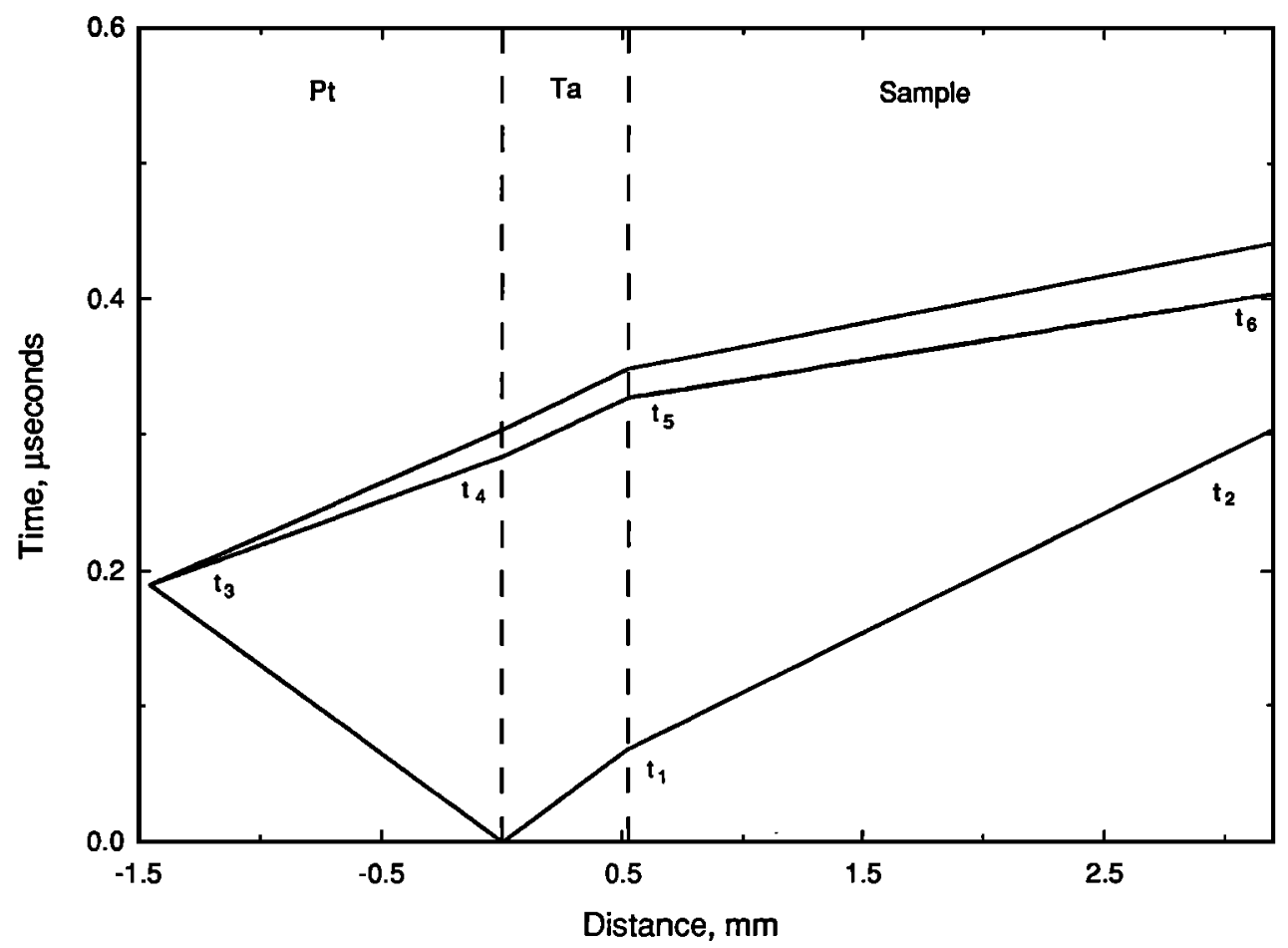

Fig. A1. Hypothetical time versus Lagrangian distance plot for target assembly and shock conditions of shot 204 , assuming that the equation of state of the sample is that of the serpentine high pressure phase (see text). Impact occurs at time $t=0$. At time $t_{1}$ the forward traveling shock reaches the Ta driver-sample interface; at time $t_{2}$ it reaches the free surface of the sample. The rearward traveling shock in the flyer reaches the rear flyer surface at $t_{3}$ and then propagates forward as a rarefaction wave, reaching the sample free surface at time $t_{6}$. Figure indicates that longitudinal attenuation of the shock wave is unlikely to have occurred in these experiments. 
dimensions. The solid curve is a plot of release angle calculated using $\gamma_{0}=1.0$ and $n=1.5$. The dashed curves result when $\gamma_{0}$ is decreased (upper dashed curve) or increased (lower dashed curve) by a factor of 2 . The plot suggests that lateral attenuation could be a problem in several of the shots, particularly shot $185\left(\mathrm{P}_{\mathrm{H}}=110 \mathrm{GPa}\right)$. However, because calculated sound speeds on the Hugoniot are very dependent

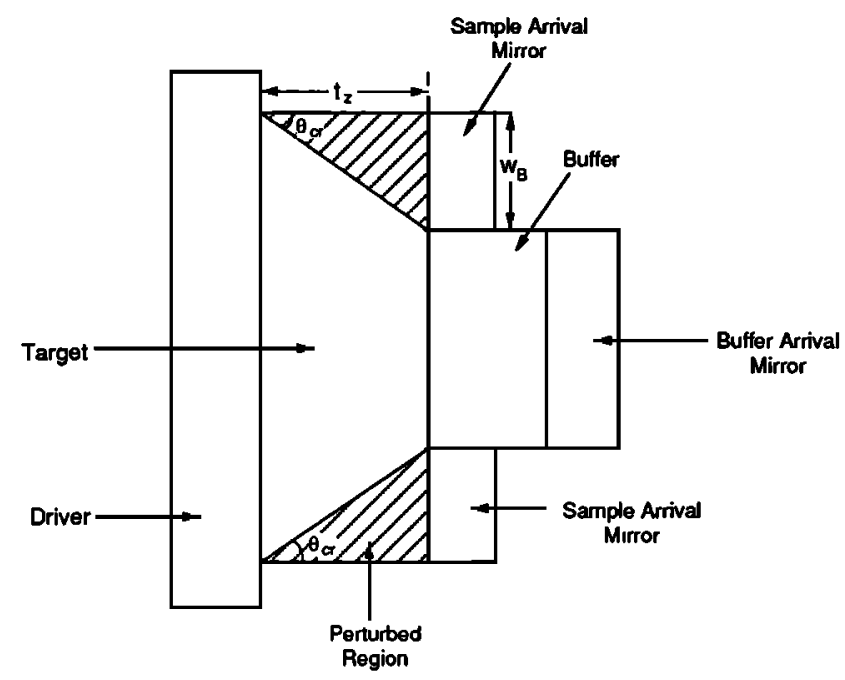

Fig. A2. Sketch showing geometry of lateral attenuation in shock equation of state experiment. Release waves propagating from the sides of the sample disturb the sample arrival mirror. If total disruption of the mirror occurs, an erroneous equation of state datum can result. Sample thickness is $w_{\mathrm{B}}$; sample arrival mirror thickness is $\mathrm{t}_{\mathrm{z}}$; critical angle for total sample mirror attenuation is $\theta_{\mathrm{cr}}$.

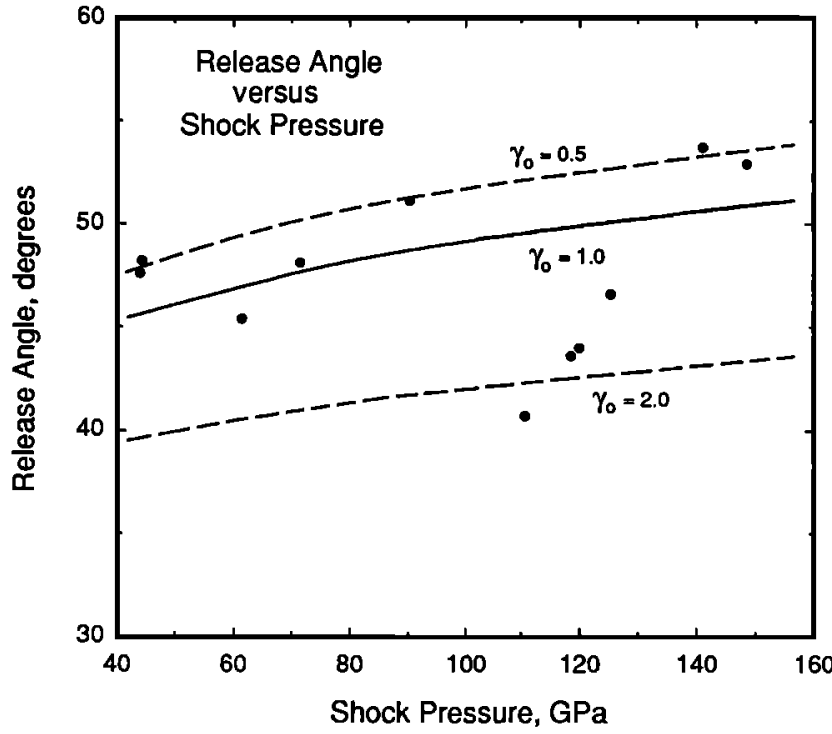

Fig. A3. Release angle $\theta$ versus shock pressure $P_{H}$ for the high pressure region of the serpentine Hugoniot. Solid dots are critical release angle $\theta_{\mathrm{cr}}$ calculated from sample dimensions (Figure A3); solid curve is release angle calculated using equation (A4) with $\gamma_{0}=1.0$ and $n=1.5$. Dashed curves are release angle calculated assuming $\gamma_{0}=0.5$ (upper dashed curve) and $\gamma_{0}=\mathbf{2 . 0}$ (lower dashed curve). on the values of the parameters employed, particularly $\gamma$, and because there are no indications of lateral disruption in the photographic shot records, we feel that these release angle estimates do not justify rejection of any of the shock data. In particular, the shots into the VHPP regime (shots 204 and 231) are among the most secure data points with respect to possible lateral and longitudinal attenuation.

Acknowledgments. We thank Epaprodito Gelle and Mike Long for experimental assistance. Sue Selkirk helped prepare the figures. Paul Carpenter provided some of the electron microprobe data. Emmerich Knoebl helped with the phase equilibrium calculations. Simon Peacock provided valuable discussion and insight. The research was primarily supported by NSF and NASA grants to T.J.A. with contributions from NSF grants to J.A.T. Contribution 4937, Division of Geological and Planetary Sciences, California Institute of Technology.

\section{References}

Abe, Y., and T. Matsui, The formation of an impact-generated $\mathrm{H}_{2} \mathrm{O}$ atmosphere and its implications for the early thermal history of the Earth, Proc. Lunar Planet. Sci. Conf., 15th, Part 2, J. Geophys. Res., 90, C545-C559, 1985.

Ahrens, T. J., Equations of state of iron sulfide and constraints on the sulfur content of the Earth, J. Geophys. Res., 84, 985-998, 1979.

Ahrens, T. J., Shock wave techniques for geophysics and planetary physics, in Methods in Experimental Physics, edited by C. Sammis and T. L. Heyney, vol. 24, part A, pp. 185-235, Academic, San Diego, Calif., 1987.

Ahrens, T. J., and R. Jeanloz, Pyrite: Shock compression, isentropic release, and composition of the Earth's core, $J$. Geophys. Res., 92, 10363-10375, 1987.

Ahrens, T. J., and J. D. O'Keefe, Shock vaporization and the accretion of the icy satellites of Jupiter and Saturn, in Ices in the Solar System, edited by J. Klinger, D. Benest, A. Dollfus, and R. Smoluchowski, pp. 631-654, D. Reidel, Dordrecht, Holland, 1985.

Ahrens, T. J., C. F. Peterson, and J. T. Rosenberg, Shock compression of feldspars, J. Geophys. Res., 74, 27272746, 1969.

Ahrens, T. J., I. Jackson, and R. Jeanloz, Shock compression and adiabatic release of a titaniferous mare basalt, Proc. Lunar Sci Conf., 8th, 3437-3455, 1977.

Ahrens, T. J., J. D. O'Keefe, and M. A. Lange, Formation of atmospheres during accretion of the terrestrial planets, in Origin and Evolution of Planetary and Satellite Atmospheres, edited by S. K. Atreya, J. R. Pollack, and M. S. Matthews, pp. 328-385, University of Arizona Press, Tucson, 1989.

Akaogi, M., and S. Akimoto, High-pressure stability of a dense hydrous magnesian silicate $\mathrm{Mg}_{23} \mathrm{Si}_{8} \mathrm{O}_{42} \mathrm{H}_{6}$ and some geophysical implications, J. Geophys. Res., 85, 69446948, 1980.

Al'tshuler, L. V., S. B. Kormer, M. I. Brazhnik, L. A. Vladimirov, M. P. Speranskaya, and A. I. Funtikov, The isentropic compressibility of aluminum, copper, lead, and iron at high pressures, Sov. Phys. JETP, Engl. Transl., $11,766-775,1960$. 
Anderson, D. L., Theory of the Earth, 366 pp., Blackwell Scientific, Boston, Mass., 1989.

Bakanova, A. A., V. N. Zubarev, Yu. N. Sutulov, and R. F. Trunin, Thermodynamic properties of water at high pressures and temperatures, Sov. Phys. JETP, Engl. Transl., 41, 544-548, 1976.

Berman, R. G., An internally consistent thermodynamic data for minerals in the system $\mathrm{Na}_{2} \mathrm{O}-\mathrm{K}_{2} \mathrm{O}-\mathrm{CaO}-\mathrm{MgO}-\mathrm{FeO}-$ $\mathrm{Fe}_{2} \mathrm{O}_{3}-\mathrm{Al}_{2} \mathrm{O}_{3}-\mathrm{SiO}_{2}-\mathrm{TiO}_{2}-\mathrm{H}_{2} \mathrm{O}-\mathrm{CO}_{2}$, Tech. Rep. 377, Atomic Energy of Canada Ltd., Chalk River, Ontario, 1985.

Bevington, P.R., Data Reduction and Error Analysis for the Physical Sciences, 336 pp, McGraw-Hill, New York, 1969.

Brown, J. M., and J. W. Shaner, Rarefaction velocities in shocked tantalum and the high pressure melting point, in Shock Waves in Condensed Matter, edited by J. R. Asay, R. A. Graham, and G. K. Straub, pp. 91-94, Elsevier, New York, 1984.

Brown, J. M., and T. J. Shankland, Thermodynamic parameters in the Earth as determined from seismic profiles, Geophys. J. R. Astron. Soc., 66, 579-596, 1981.

Brown, J. M., M. D. Furnish, and R. G. McQueen, Thermodynamics for $(\mathrm{Mg}, \mathrm{Fe})_{2} \mathrm{SiO}_{4}$ from the Hugoniot, in High-Pressure Research in Mineral Physics, Geophys. Monogr. Ser., vol. 39, edited by M. H. Manghnani and Y. Syono, pp. 373-384, AGU, Washington, D.C., 1987.

Brown, T. H., R. G. Berman, and E. H. Perkins, GEOCALC: Software package for calculation and display of pressure-temperature-composition phase diagrams using an IBM or compatible personal computer, Comput. and Geosci., 14, 279-289, 1988.

Chhabildas, L. C., J. R. Asay, and L. M. Barker, Shear strength of tungsten under shock- and quasi-isentropic loading to $250 \mathrm{GPa}$, Sandia Natl. Lab. Tech. Rep., SAND88-0306, 1988.

Duffy, T. S., T. J. Ahrens, and M. A. Lange, The shock wave equation of state of brucite $\mathrm{Mg}(\mathrm{OH})_{2}, J$. Geophys. Res., in press, 1991.

Dziewonski, A. M., and D. L. Anderson, Preliminary reference Earth model, Phys. Earth Planet. Inter., 25, 297356, 1981.

Finger, L. W., J. Ko, R. M. Hazen, T. Gasparik, R. J. Hemley, C. T. Prewitt, and D. J. Weidner, Crystal chemistry of phase $B$ and an anhydrous analogue: implications for water storage in the upper mantle, Nature, 341, 140-142, 1989.

Furnish, M. D., and J. M. Brown, Shock loading of singlecrystal olivine in the 100-200 GPa range, J. Geophys. Res., 91, 4723-4729, 1986.

Grady, D. E., W. J. Murri, and G. R. Fowles, Quartz to stishovite: Wave propagation in the mixed phase region, $J$. Geophys. Res., 79, 332-338, 1974.

Heinz, D. L., and R. Jeanloz, The equation of state of the gold calibration standard, J. Appl. Phys., 55, 885-893, 1984.

Holmes, N. C., J. A. Moriarty, G. R. Gathers, and W. J. Nellis, The equation of state of platinum to $660 \mathrm{GPa}(6.6$ Mbar), J. Appl. Phys., 66, 2962-2967, 1989.

Jackson, I., and T. J. Ahrens, Shock-wave compression of single crystal forsterite, J. Geophys. Res., 84, 3039-3048, 1979.
Jeanloz, R., Shock wave equation of state and finite strain theory, J. Geophys. Res., 94, 5873-5886, 1989.

Jeanloz, R., and T. J. Ahrens, Equations of state of $\mathrm{FeO}$ and $\mathrm{CaO}$, Geophys. J. R. Astron. Soc., 62, 505-528, 1980.

Jeanloz, R., and A. B. Thompson, Phase transitions and mantle discontinuities, Rev. Geophys., 21, 51-74, 1983.

Lambert, P., and M. A. Lange, Glasses produced by shock melting and devolatilization of hydrous silicates, $J$. Non Cryst. Solids, 67, 521-545, 1984.

Lange, M. A., P. Lambert, and T. J. Ahrens, Shock effects on hydrous minerals and implications for carbonaceous chondrites, Geochim. Cosmochim. Acta, 49, 1715-1726, 1985.

Liu, L.-G., Phase transformations in serpentine at high pressures and temperatures and implications for subducting lithosphere, Phys. Earth Planet. Inter., 42, 255-262, 1986.

Liu, L.-G., Effects of $\mathrm{H}_{2} \mathrm{O}$ on the phase behavior of the forsterite-enstatite system at high pressures and temperatures and implications for the Earth, Phys. Earth Planet. Inter., 49, 142-167, 1987.

Liu, L.-G., Water in the terrestrial planets and the moon, Icarus, 74, 98-107, 1988.

Lyzenga, G. A., and T. J. Ahrens, The relation between the shock-induced free-surface velocity and the postshock specific volume of solids, J. Appl. Phys., 49, 201-204, 1978 .

Marsh, S. P. (Ed.), LASL Shock Hugoniot Data, University of California Press, Berkeley, 1980.

McGovern, P. J., and G. Schubert, Thermal evolution of the Earth: effects of volatile exchange between atmosphere and interior, Earth Planet. Sci. Lett., 96, 27-37, 1989.

McQueen, R. G., S. P. Marsh, and J. N. Fritz, Hugoniot equation of state of twelve rocks, J. Geophys. Res., 72, 4999-5036, 1967.

McQueen, R. G., S. P. Marsh, J. W. Taylor, J. N. Fritz, and W. J. Carter, The equation of state of solids from shock wave studies, in High Velocity Impact Phenomena, edited by R. Kinslow, pp. 249-419, Academic, San Diego, Calif., 1970.

McQueen, R. G., J. N. Fritz, and C. E. Morris, The velocity of sound behind strong shock waves in $2024 \mathrm{Al}$, in Shock Waves in Condensed Matter - 1983, edited by J. R. Asay, R. A. Graham, and G. K. Straub, pp. 95-98, Elsevier, New York, 1984.

Meade, C., and R. Jeanloz, Acoustic emissions from serpentine at high pressures and low temperatures: Implications for the origin of deep-focus earthquakes (abstract), Eos Trans. AGU, 70, 1321, 1989.

Meade, C., and R. Jeanloz, Deep-focus earthquakes and recycling of water into the Earth's mantle, Science, 252, 68-72, 1991.

Meister, R., E. C. Robertson, R. W. Werre, and R. Raspet, Elastic moduli of rock glasses under pressure to 8 kilobars and geophysical implications, J. Geophys. Res., 85, 64616470, 1980.

Mitchell, A. C., and W. J. Nellis, Shock compression of aluminium, copper, and tantalum, J. Appl. Phys., 52, 3363-3374, 1981.

Mitchell, A. C., and W. J. Nellis, Equation of state and electrical conductivity of water and ammonia shocked to the $100 \mathrm{GPa}$ (1 Mbar) pressure range, J. Chem. Phys., 76, 6273-6281, 1982. 
Morgan, J. A., The equation of state of platinum to $680 \mathrm{GPa}$, High Temp. High Pressures, 6, 195-201, 1974.

Peacock, S. M., Fluid processes in subduction zones, Science, 248, 329-337, 1990.

Press, F., Seismic velocities, in Handbook of Physical Constants, edited by S. P. Clark, Jr., U.S. Geol. Surv. Mem. 97, 195-218, 1966.

Rice, M. H., R. G. McQueen, and J. M. Walsh, Compression of solids by strong shock waves, Solid State Phys., 6, 163, 1958.

Ringwood, A. E., Composition and Petrology of the Earth's Mantle, 618 pp., McGraw-Hill, New York, 1975.

Ringwood, A. E., and A. Major, High-pressure reconnaissance investigations in the system $\mathrm{Mg}_{2} \mathrm{SiO}_{4}-$ $\mathrm{MgO}-\mathrm{H}_{2} \mathrm{O}$, Earth Planet. Sci. Lett., 2, 130-133, 1967.

Robie, R. A., B. S. Hemingway, and J. R. Fisher, Thermodynamic Properties of Minerals and Related Substances at $298.15 \mathrm{~K}$ and $1 \mathrm{Bar}\left(10^{5}\right.$ Pascals) Pressure and at Higher Temperatures, U.S. Geol. Surv. Bull., 1452, 1978.

Simakov, G. V., M. N. Pavlovsky, N. G. Kalashnikov, and R. F. Trunin, Shock compressibility of twelve minerals, Izv. Earth Phys., 10, 11-17, 1974.

Stacey, F. D., A thermal model of the Earth, Phys. Earth Planet. Inter., 15, 341-348, 1977.

Trunin, R. F., V. I. Gon'shakova, G. V. Simakov, and N. E. Galdin, A study of rocks under the high temperatures created by shock compression, Izv., Earth Phys., 8, 579$586,1965$.

Tyburczy, J. A., R. V. Krishnamurthy, S. Epstein, and T. J. Ahrens, Impact-induced devolatilization and hydrogen isotopic fractionation of serpentine: Implications for planetary accretion, Earth Planet. Sci. Lett, 98, 245-261, 1990.

Walker, J. C. G., Evolution of the Atmosphere, 318 pp., MacMillan, New York, 1977.

Watt, J. P., and T. J. Ahrens, Shock compression of single crystal forsterite, J. Geophys. Res., 88, 9500-9512, 1983.

Watt, J. P., and T. J. Ahrens, Shock wave equation of state of enstatite, J. Geophys. Res., 91, 7495-7503, 1986.

Watt, J. P., G. G. Davies, and R. J. O'Connell, The elastic properties of composite materials, Rev. Geophys. Space Phys., 14, 541-563, 1976.

Yamamoto, $\mathrm{K}$, and S. Akimoto, The system $\mathrm{MgO}-\mathrm{SiO}_{2}-\mathrm{H}_{2} \mathrm{O}$ at high pressures and temperatures - Stability field for hydroxyl-chondrodite, hydroxyl clinohumite, and $10 \AA$ phase, Am. J. Sci., 277, 288-312, 1977.

Zahnle, K. J., J. F. Kasting, and J. B. Pollack, Evolution of a steam atmosphere during Earth's accretion, Icarus, 74, 6297, 1988.

T.J. Ahrens and T.S. Duffy, Seismological Laboratory, 252-21, California Institute of Technology, Pasadena, CA 91125.

M.A. Lange, Alfred Wegener Institute for Polar and Marine Research, Postfach 120161, D-2850 Bremerhaven, Federal Republic of Germany.

J.A. Tyburczy, Department of Geology, Arizona State University, Tempe, AZ 85287-1404.

(Received September 11, 1990; revised May 23, 1991; accepted June 11, 1991.) 